\title{
ARTÍCULOS
}

\section{ENTRE MÉXICO Y ESPAÑA. DE LA EMIGRACIÓN A LA CONSTRUCCIÓN DE UNA IMAGEN DE PODER: BRUNO ZALDO (1836-1916).}

\author{
Juan José Martín García \\ Universidad de Burgos \\ ïmgarcia@ubu.es \\ María José Zaparaín Yáñez \\ Universidad de Burgos \\ mizaparain@ubu.es
}

Resumen: Bruno Zaldo Rivera (Pradoluengo - España, 1836-1916) constituye un ejemplo del emigrante que triunfó "haciendo las Américas". En este artículo se perfila la figura de un hombre que, con apenas estudios básicos, y gracias a su trabajo y perspicacia, fue capaz de aprovechar las oportunidades en las esferas económica y social, desde sus inicios como pequeño comerciante en el emporio mexicano de Veracruz, hasta su elección como senador de España. La investigación demostrará su versatilidad empresarial y su generosidad en forma de innumerables donaciones y fundaciones. El análisis de sus iniciativas como promotor inmobiliario y banquero de éxito, y sus relaciones sociales y políticas, explican su acceso hasta el selecto grupo de la alta sociedad española de la Restauración. Por último, se comprobará cómo, el arte, en todas sus expresiones, supuso un instrumento para la consolidación de su prestigio y para la elaboración de su imagen como prohombre de la Nación.

Palabras clave: Emigración, economía capitalista, filantropía, arte, poder, Veracruz, Madrid.

Tittle: BETWEEN MEXICO AND SPAIN. FROM EMIGRATION TO THE CONSTRUCTION OF AN IMAGE OF POWER: BRUNO ZALDO (1836-1916).

Abstract: Bruno Zaldo Rivera (Pradoluengo - España, 1836-1916) represents an example of the emigrant who triumphed "haciendo las Americas" [making it in the Americas]. In this paper, a man is profiled who, with hardly the most basic studies, and thanks to his endeavors and perspicacity, was capable of benefitting from the opportunities, both in economic and in social spheres, from his beginnings as a small-time merchant in the Mexican emporium of Veracruz, to his election as a senator of Spain. The investigation demonstrates his entrepreneurial versatility and his generosity in the form of innumerable donations and foundations. The analysis of his initiatives as a real-estate promotor and successful banker, and his social and political relations, explain his accession to a group within the high society of the Spanish Restauration. Finally, it will be shown how art, in all of its expressions, was subsumed as an instrument for the consolidation of his prestige and for the preparation of his image as a distinguished gentleman of the Nation.

Cómo citar este artículo: MARTíN GARCÍA, Juan José y ZAPARAÍN YÁÑEZ, María José. Entre México y España. De la emigración a la construcción de una imagen de poder: Bruno Zaldo (18361916). Naveg@mérica. Revista electrónica editada por la Asociación Española de Americanistas [en línea]. 2020, n. 25. Disponible en: <http://revistas.um.es/navegamerica>. [Consulta: Fecha de consulta]. ISSN 1989-211X. 
Juan José MARTíN GARCÍA y María José ZAPARAÍN YÁÑEZ. Entre México y España. De la emigración a la construcción de una imagen de poder: Bruno Zaldo (1836-1916).

Keywords: Emigration, capitalist economy, philanthropist, art, power, Veracruz, Madrid.

\section{Introducción}

Son muchos los trabajos sobre la emigración española hacia América. Un corpus tan abultado que, por fuerza, para perfilar con cierta precisión nuestro contexto espacio-temporal, deberemos centrar, principalmente, en recordar aquellos que abarcan la etapa que más nos interesa aquí, -la contemporánea y, en concreto, la segunda mitad del siglo XIX-y el ámbito específico de uno de los principales territorios receptores de esta emigración -México- que, como es sabido, atrajo fundamentalmente a emigrantes del tercio norte peninsular. Estos mantuvieron dinámicas de actuación homogéneas por su extracción social, instrucción y cultura, dedicaciones preferentes -comercio, profesiones liberales, etc.- y comportamientos sociales a uno y otro lado del Atlántico ${ }^{1}$.

${ }^{1}$ Sin ánimo de exhaustividad se pueden señalar: IDOATE ANCíN, Raquel. Emigración de la Navarra atlántica a América en el siglo XIX (1840-1874) [tesis doctoral]. Navarra: Universidad Pública de Navarra, 2020; AZCONA PASTOR, José Manuel. Los fundamentos de la emigración española hacia América (siglos XVI-XXI). En: AZCONA PASTOR, José Manuel; MARTíN DE LA GUARDIA, Ricardo y PÉREZ SÁNCHEZ, Guillermo A. (eds.). España en la era global (1492-1898). Madrid: Sílex Universidad, 2017, pp. 361-404; SÁNCHEZ ANDRÉS, Agustín y PÉREZ HERRERO, Pedro. Historia de las relaciones entre España y México, 1821-2014. Madrid: Marcial Pons, 2016; REBOLLEDO KLOQUES, Octavio Bernardo. Extranjeros, nacionalismo y política migratoria en el México independiente, 1821-2000 [tesis doctoral]. Granada: Universidad de Granada, 2016; ÁLVAREZ GILA, Óscar y AMORES CARREDANO, Juan Bosco (coords.). Del espacio cantábrico al mundo americano. Perspectivas sobre migración, etnicidad y retorno. Bilbao: Universidad del País Vasco, 2015; AZCONA PASTOR, José Manuel (ed.). Identidad y estructura de la emigración vasca y navarra hacia Iberoamérica siglos (XVI-XXI). Thomson Reuters Aranzadi, 2015; ARBELO GARCIA, Adolfo. Correspondencia canario-americana: familia y redes sociales (siglos XVIII y XIX). Madrid: Idea, 2011; VV.AA. La memoria de la emigración: fuentes históricas, centros y archivos para el estudio de los flujos migratorios españoles. Vigo: Grupo España Exterior, 2011; RUIZ DE GORDEJUELA URQUIJO, Jesús. Vivir y morir en México. Vida cotidiana en el epistolario de los españoles vasco-navarros 1750-1900. San Sebastián: Ediciones Nuevos Aires, 2011; MORALES MORENO, Humberto. Los Españoles de México: 1880-1948. Asturianos, Montañeses y Vascos en la formación de redes microsociales en la época de la emigración "en masa" y del exilio en México. Gijón: CICEE, 2010; DOMÍNGUEZ MARTÍN, Rafael. Empresarios y hombres de negocios cántabros en México durante los siglos XIX y XX. Revista de la historia de la economía y de la empresa. 2008, n. 2, pp. 155-180; HERNÁNDEZ GONZÁLEZ, Manuel. La emigración canaria a América a través de la historia. Cuadernos Americanos. 2008, vol. 4, n. 126, pp. 137-172; BLANCO RODRíGUEZ, Juan Andrés (ed.). El asociacionismo en la emigración española a América. Zamora: Junta de Castilla y León, 2008; SÁNCHEZ ALONSO, Blanca. The other Europeans: inmigration into Latin America and the International Labour Market (1870-1930). Revista de Historia Económica. Journal of Iberian and Latin American Economic History. 2007, vol. 25, n. 3, pp. 395-426; DOMÍNGUEZ MARTÍN, Rafael y CERUTTI PIGNAT, Mario (coords.). De la colonia a la globalización: empresarios cántabros en México. Santander: Universidad de Cantabria, 2006; LIDA, Clara Eugenia. Los españoles en el México independiente: 1821-1950. Un estado de la cuestión. Historia mexicana. 2006, vol. 56, n. 2, pp. 213-260; PI-SUÑER LLORENS, Antonia y SÁNCHEZ ANDRÉS, Agustín. Una historia de encuentros y desencuentros: México y España en el siglo XIX. México: Secretaría de Relaciones Exteriores, 2001; RUEDA HERNANZ, Germán y SOLDEVILLA ORIA, Consuelo. Españoles emigrantes en América (siglos XVI-XX). Madrid: Arco, 2000; SOLÀ I PARERA, Àngels. Os americanos cataláns e o seu impacto económico en Cataluña ó longo do século XIX. Estudios migratorios. 2001, n. 11-12, pp. 141-168; SÁNCHEZ ANDRÉS, Agustín. La normalización de las relaciones entre España y México durante el Porfiriato (1876-1910). Historia mexicana. 1999, vol. 48, n. 4, pp. 731-766; SÁNCHEZ ALONSO, Blanca. Las causas de la emigración española, 1880-1930. Madrid: Alianza Editorial, 1995; LIDA, Clara Eugenia (comp.). Una inmigración privilegiada. 
Esta emigración y, por ende, el ejemplo que nos ocupa en la investigación, presentó características propias que, cronológicamente, la sitúan a medio camino entre la expulsión de los españoles de México (1821-1828), y la denominada "emigración en masa" (1880-1930), periodos ambos que también han llamado la atención de la historiografía ${ }^{2}$.

Lógicamente, como todo proceso histórico, este fenómeno migratorio se encuentra en una etapa intermedia entre los dos periodos señalados y, por lo que respecta a su funcionamiento interno, se basa en esquemas asentados con anterioridad. En concreto, hay una serie de características de los comerciantes de origen español, que ya vienen apuntadas en las décadas que van desde finales del siglo XVIII hasta el primer tercio de la centuria siguiente. Como señala Jesús Turiso Sebastián, -quien, así mismo, estudia a los comerciantes de la región veracruzana donde recaló nuestro protagonista- veremos repetirse los mismos modos de actuación en la figura de Bruno Zaldo, sus hermanos, sus parientes y sus paisanos.

Así, entre estos españoles -dedicados a distintas actividades económicasabundan los comerciantes al por mayor o "almaceneros" que, en primer lugar, buscan hacerse con un local o centro de operaciones que funcionará a su vez como vivienda. A su frente, se situaba un familiar o un paisano, lo que era aprovechado por los jóvenes aprendices para iniciarse en la carrera mercantil. El funcionamiento cotidiano de estas células económicas se basaba en el de la familia, que no dejaba de ser remedo de una verdadera empresa. Una red de familiares -hermanos, primos, parientes- que, en ocasiones, se ampliaba al paisanaje -como en el caso de los riojanos Elías, los

Comerciantes, empresarios y profesionales españoles en México en los siglos XIX y XX. Madrid: Alianza Editorial, 1994; VIVES, Pedro A.; VEGA, Pepa y OYAMBURU, Jesús (coords). Historia general de la emigración española a lberoamérica. Ministerio de Trabajo e inmigración, 1992; EIRAS ROEL, Antonio (coord.). La emigración española a Ultramar, 1492-1914. Madrid: Tabapress, 1991; SÁNCHEZ ALBORNOZ, Nicolás (coord.). Españoles hacia América. La emigración en masa, 1880-1930. Madrid: Alianza Editorial, 1988.

2 RUIZ DE GORDEJUELA URQUIJO, Jesús. Remesas de caudales españoles durante los primeros años del México independiente, 1821-1827. Revista complutense de Historia de América. 2016, n. 42, pp. 293-317; RUIZ DE GORDEJUELA URQUIJO, Jesús. Retorno de los comerciantes españoles tras la independencia de México. Temas americanistas. 2016, n. 37, pp. 217-240; RUIZ DE GORDEJUELA URQUIJO, Jesús. Emigración vasco-navarra a México a mediados del siglo XIX. De Santa Anna a Juárez, 1842-1867. Vasconia: Cuadernos de historia - geografía. 2012, n. 38, pp. 385-404; GÁRATE OJANGUREN, Montserrat. Los modelos de trasvases de capitales de América a Europa e inversiones en el siglo XIX. En: BEASCOECHEA GANGOITI, José María; NOVO LÓPEZ, Pedro A. y GONZÁLEZ PORTILLA, Manuel (eds.). La ciudad contemporánea, espacio y sociedad. Bilbao: Universidad del País Vasco, 2006, pp. 737-766; GÁRATE OJANGUREN, Montserrat. Circuitos comerciales y financieros entre México y Europa (1800-1850): la participación vasca. En: YUSTE LÓPEZ, Carmen y SOUTO MANTECÓN, Matilde (coords.). El comercio exterior de México: 1713-1850. México: Instituto de Investigaciones Históricas; UNAM-Universidad Veracruzana, 2000, pp. 223-259; CERUTTI PIGNAT, Mario. Españoles y empresariado en el norte de México. Los papeles del vasco José San Román. América Latina en la Historia Económica. 1998, vol. 5, n. 9, pp. 17-24; CERUTTI PIGNAT, Mario. Empresarios españoles y sociedad capitalista en México (1840-1920). Colombres: Archivo de Indianos, 1995; SOUTO MANTECÓN, Matilde. Los comerciantes españoles en Veracruz: del Imperio colonial a la República. En: LIDA, Clara Eugenia (comp.). Una inmigración privilegiada: comerciantes, empresarios y profesionales españoles en México en los siglos XIX y XX. Madrid: Alianza, 1994, pp. 52-74; SOLÀ I PARERA, Àngels. La Independencia mexicana y la salida de capitales españoles residentes en México (1810-1830). En: Industrialización y nacionalismo. Actas del 1ํㅡoloquio vascocatalán de historia. Barcelona: Universidad de Barcelona, 1985, pp. 339-354. 
sorianos Badillo, etc.- y que se retroalimentaba. También era común la figura del apoderado, quien, en ausencia del comerciante, podía comprar, vender, cobrar y cancelar deudas. La asociación con otros comerciantes, normalmente paisanos o peninsulares, era otra fórmula de actuación a la hora de asegurar fletes y, por tanto, aminorar posibles pérdidas. Por último, la participación en operaciones financieras y la diversificación de actividades económicas, fue fundamental para el éxito de estos grandes comerciantes ${ }^{3}$.

Si bien el número de españoles emigrantes a México no fue significativo desde el punto de vista cuantitativo, sus capacidades cualitativas, como propietarios y emprendedores de distintos sectores económicos en la segunda mitad del siglo XIX, están fuera de toda duda. En palabras de Mario Cerutti, estos hombres, "se convirtieron en un factor -el empresarial- de alta significación en el proceso formativo de la sociedad capitalista autóctona". Las múltiples actividades que llevaron a cabo y su elevada proporción numérica dentro de la burguesía de los negocios, supusieron un enorme peso cualitativo en el desarrollo capitalista mexicano ${ }^{4}$.

La crisis económica, consustancial a buena parte de la contemporaneidad española y definitoria de la segunda mitad de su siglo XIX, se vio atemperada -al igual que sucedió en otros países europeos- mediante una eficaz válvula de escape: la emigración. En este sentido, la búsqueda de un futuro fuera de su país por parte de miles de peninsulares jugó dos papeles trascendentales: aminorar el número de bocas menesterosas que alimentar, y propiciar el retorno de medios económicos y herramientas financieras con las que posibilitar el crecimiento interno.

Nuestro protagonista, Bruno Zaldo, aprovechó las oportunidades que se le presentaron a lo largo de su periplo vital, hasta construir la imagen de un sólido triunfador en las esferas económica, social y política de la España de la Restauración. No en vano, pasó de ser un humilde emigrante español en el emporio mexicano de Veracruz, a retornar a su país con los suficientes "posibles" como para hacerse un hueco entre la más alta sociedad madrileña, culminando su carrera con la dignidad senatorial del Reino de España.

Evidentemente, este viaje, entre orígenes modestos y culmen social, se fraguó a base de un abanico de circunstancias conjugadas de trabajo y fortuna, que fueron mediatizadas por un carácter emprendedor y previsor, capaz de diversificar negocios, pero, al tiempo, de asentar su riqueza. Como se recordaba en el momento de su mayor ascenso profesional: "el Sr. Zaldo es uno de los pocos millonarios de la capital que no muestra repugnancia a los negocios industriales, sino al contrario, parece complacerse en favorecerlos"

3 TURISO SEBASTIÁN, Jesús. Emigración, comerciantes y comercio en la región de Veracruz entre 1778-1822. Naveg@mérica, Revista electrónica editada por la Asociación Española de Americanistas [en línea]. 2019, n. 22, pp. 11-22. Disponible en $<$ https://revistas.um.es/navegamerica/article/view/363601/258911>.

4 CERUTTI PIGNAT, Mario. Españoles y empresariado en el norte de México... Op. cit., p. 19. EI comercio al por mayor, sus relaciones con el crédito prebancario, las inversiones en tierras, industrias fabriles, minería, transportes, agroindustria y servicios fueron fundamentales para el desarrollo de grandes empresas en la segunda mitad del México decimonónico.

${ }_{5}^{5}$ Revista Minera, Metalúrgica y de Ingeniería. 16 de abril de 1889, Año XL, n. 1.245, pp. 118-119. 
Así, cada operación cerrada por el emigrante pradoluenguino, se convertía en el punto de partida de una nueva iniciativa emprendedora, abarcando gran parte de los sectores que, por entonces, ofrecían perspectivas de futuro. Por tanto, Bruno fue un hombre innovador, que aprovechó las posibilidades de su tiempo en torno al desarrollo de nuevas técnicas y al espíritu de progreso, aunando su inteligencia con la capacidad del "hombre que solo sabía trabajar", como también fue definido en su momento.

Esta aptitud para conjugar diferentes líneas de actuación desborda lo económico para entrar de lleno en un concepto de socialización a través de dos campos destacados: el arte y la filantropía, siguiendo una línea de actuación ampliamente contrastada entre quienes compartían los mismos orígenes de su fortuna. Ambos cauces le reportarán réditos significativos que retroalimentarán sus intereses económicos y su posicionamiento social, configurando una imagen de poder en la que aunaba la atractiva personalidad de exitoso hombre de negocios capitalista, con la de la bonhomía desprendida de sus preocupaciones sociales por los más desfavorecidos, siempre desde una óptica caritativa de orden fundamentalmente católico, aunque no exenta de matices "modernos".

Consciente de su procedencia, armonizó en su carácter los aspectos puramente pragmáticos de su ascenso socioeconómico, con los propios de una naturaleza humana sumamente generosa que no olvidaba las penurias de su infancia. Así era descrito por el periódico La Época cuando contaba con 47 años: "El contratista de las obras de la Cárcel nueva se llama Don Bruno Zaldo y es un individuo bajo, rechoncho, de aspecto apacible y sonriente. Poseía algunos bienes de fortuna, jugó a la lotería por Navidad hace algunos años, le tocó el premio gordo -ique ya es tocar!- y sin andarse por las ramas tomó la contrata en cuestión. Por ella cobrará en dinero y solares (...) unos veinticinco millones de reales. - ¿Pero qué va a hacer usted con tantos millones? Le pregunté contemplándole como si hubiera crecido en estatura de tal modo que alcanzase con la mano el último piso del ministerio de Hacienda. -Soy socialista práctico -repuso- así como voy recibiendo el dinero lo voy repartiendo por aquí y por allá"6.

En el desarrollo del estudio se han examinado las publicaciones concretas existentes sobre su figura ${ }^{7}$. No obstante, ante la dimensión del personaje, se ha profundizado mediante el manejo múltiples fuentes primarias, recurriendo no solo a archivos de su localidad natal y del ámbito provincial burgalés, sino también de la ciudad de Veracruz y, muy especialmente, de Madrid. La consulta de estos últimos ha ofrecido notables hallazgos que permiten descubrir mejor su diversidad empresarial, así como perfilar algunos aspectos hasta ahora menos conocidos de sus actividades, concretamente su relación con el mundo de la construcción, su papel como promotor inmobiliario y los vínculos establecidos con algunos de los principales arquitectos del Madrid de la Restauración. Todo ello se ha completado con un exhaustivo rastreo de las publicaciones periódicas contemporáneas de las que se convirtió en uno de sus

\footnotetext{
${ }^{6}$ La Época. 29 de noviembre de 1883, n.11.273, p. 2.

7 MARTín GARCíA, Juan José. Trabajo rural-Trabajo industrial: Belorado y Pradoluengo (1833-1936). Burgos: Aytos. de Belorado y Pradoluengo, 2000; MARTíN GARCÍA, Juan José. "Zaldo Rivera, Bruno". En: Diccionario Biográfico Español, vol. 50. Madrid: Real Academia de la Historia, 2013; ZALDO HERNÁNDEZ, Rafael. Indianos ilustres. Familia Zaldo. Burgos: Ed. del autor, 2013.
} 
destacados protagonistas y que, dada su pluralidad, permiten configurar las diferentes facetas de su rica personalidad y polifacética actuación.

\section{Orígenes castellanos y primeros pasos en el emporio de Veracruz}

Bruno Zaldo Rivera nació el 6 de octubre de 1836, en la localidad española de Pradoluengo (Burgos) ${ }^{8}$, villa enclavada en la Sierra de la Demanda, caracterizada por su dedicación secular a la industria textil lanera. Como los cercanos Cameros riojanos, este pueblo se convirtió en un importante foco emisor de emigrantes hacia América debido a las crisis cíclicas que afectaron dicha actividad ${ }^{9}$. Bruno fue el mayor de nueve hermanos, de los que sobrevivieron a una dura infancia tan solo seis. Sus padres eran mayordomos, es decir, capataces, en concreto de la fábrica de hilaturas denominada La Nueva. Aunque la situación económica familiar no era tan precaria como la de la necesitada clase obrera local, tantas bocas que alimentar y la posibilidad de mejora que ofrecía la salida de su población natal, le condujeron, siendo prácticamente un niño de entre 14 y 15 años, a trabajar en un comercio de Madrid, donde estuvo ocupado alrededor de cuatro temporadas ${ }^{10}$. Este último dato, desconocido hasta el momento, es relevante a la hora de explicar el porqué de su retorno a la Villa y Corte tras su exitosa experiencia mexicana, frente a la opción de otros centros que, como Barcelona o Bilbao, también eran atractivos para quienes regresaban de América ${ }^{11}$.

Con los primeros rudimentos comerciales -ya que tan sólo contaba con estudios primarios-, pudo satisfacer una de sus aspiraciones y dar el salto en "busca de las Américas"12, instalándose como aprendiz en una tienda del puerto mexicano de Veracruz, donde llegó entre 1855 y 1856 . Una forma de actuar esta, la de adiestrarse en actividades mercantiles en casas ya establecidas, muy común entre los emigrantes peninsulares ${ }^{13}$. El punto de inflexión en su ascenso se puede fijar el 30 de junio de 1859, cuando, con 22 años, adquiere un modesto establecimiento, embrión de una futura casa comercial que le abrirá nuevas expectativas ${ }^{14}$.

En 1862 tuvo lugar uno de los primeros episodios que forjaron el carácter de Zaldo como comerciante y hombre de negocios. En plena intervención francesa en México, su perspicacia le hizo plantearse que suministrar mercancías a ciertas zonas del país

\footnotetext{
${ }^{8}$ Archivo Parroquial de Pradoluengo (APP). Libro n. 7 de bautismos (1827-1840), fol. 235.

${ }^{9}$ MARTíN GARCÍA, Juan José. La industria textil de Pradoluengo, 1534-2007. La pervivencia de un núcleo industrial. Valladolid: Junta de Castilla y León, 2007.

10 Revista Ilustrada de Banca, Ferrocarriles, Industria y Seguros. 25 de junio de 1910, Tomo XVIII, n. 12, p. 292.

${ }^{11}$ ARAMBURU-ZABALA HIGUERA Miguel Ángel y SOLDEVILLA ORIA, Consuelo. Arquitectura de los indianos en Cantabria (siglos XVI-XX). El patrimonio de la emigración Trasatlántica. Santander: Ediciones Librería Estudio, 2007, p. 46; PALIZA MONDUATE, $M^{a}$ Teresa. El mecenazgo de los indianos en el País Vasco. Personajes, sagas y su vinculación con el arte y la filantropía (siglos XIX y XX). En: SAZATORNIL Ruiz, Luis (ed.). Arte y mecenazgo indiano: del Cantábrico al Caribe. Gijón: Ediciones Treas, 2007, pp. 435-460.

12 RUEDA HERNANZ, Germán. Los españoles de allá... Op. cit., pp. 411-412. Bruno se englobaría dentro del $20 \%$ de jóvenes emigrantes españoles que se dedicaban en España al comercio y la industria.

${ }^{13}$ CERUTTI PIGNAT, Mario. Españoles y empresariado en el norte de México... Op. cit., p. 17.

${ }^{14}$ Revista llustrada de Banca, Ferrocarriles, Industria y Seguros 10 de julio de 1897, Año Quinto, p. 193.
} 
le ofertaría pingües beneficios. Asociado con su amigo Raimundo Lapuente, fletó un pequeño buque con destino a Nautla para, desde allí, transportar artículos de consumo hasta Teziutlan. Aunque el barco naufragó, su sentido previsor le había hecho asegurar el cargamento. Fue la ocasión de no arredrarse y de fletar un nuevo bajel en el que se embarcaron los dos socios: "Esta vez las mercancías no iban aseguradas [...] Si el barco se perdía, los dueños del cargamento corrían la misma suerte; era pues inútil asegurarlo"15. El segundo intento salió bien.

Los primeros éxitos comerciales fueron muy rentables y provocaron un efecto llamada con la fuerza de un imán para hermanos, familiares directos, parientes y paisanos, aspecto favorecido por el periodo político mexicano de la época, en el que estaba tomando forma la legislación liberal de la nación. Sus hermanos Dionisio y Eugenio ya aparecen domiciliados en el veracruzano callejón de San Vicente al menos desde agosto de 1864, viviendo en el almacén de ropa propiedad de Bruno ${ }^{16}$. Posteriormente, lo harán sus otros dos hermanos varones, Clemente y Gervasio. En septiembre de ese mismo año, Bruno regresó temporalmente a Pradoluengo, protocolizando, con tan solo 27 años, uno de sus primeros testamentos ${ }^{17}$. Una de las fechas fundamentales en su consolidación como hombre de fortuna fue el 13 de diciembre de 1866, cuando fundó la sociedad mercantil Zaldo Hermanos y Compañía, que conjugará intereses económicos y personales de ambos lados del Atlántico durante décadas.

Apenas año y medio después, el 13 de julio de 1868, embarcaba en el vapor France con destino a La Habana ${ }^{18}$. Once días antes había firmado un protocolo en el que apoderaba a su antiguo socio Lapuente para representarle en la sociedad familiar. De la capital cubana pasó a Nueva York y, vía Hamburgo, llegó a España.

Aunque el pionero de la saga puede encuadrarse en ese $17,7 \%$ de emigrantes retornados que, grosso modo, volvieron entre 1825 y $1881^{19}$, en la práctica mantuvo la conexión de intereses económicos, culturales y personales con México hasta su muerte.

Pocos meses después de su regreso, el 6 de mayo de 1869, casaba con 32 años con la pradoluenguina Vitoria Arana Villar, hija del fabricante de bayetas Ceferino Arana, aportando al matrimonio la extraordinaria cifra de 1.432 .420 reales, de los cuales, 233.580 eran beneficios obtenidos en tan solo dos años de funcionamiento de la compañía de comercio, lo que indica su elevada rentabilidad ${ }^{20}$. La esposa aportó al contrato matrimonial 30.000 reales, procedentes de un prado y diverso ajuar ${ }^{21}$. Estos retornos para maridar en la patria chica eran habituales entre los emigrantes

${ }^{15}$ Revista Ilustrada de Banca, Ferrocarriles, Industria y Seguros. 25 de junio de 1910, Tomo XVIII, n. 12, p. 292.

${ }^{16}$ Archivo Histórico Municipal de Veracruz (AHMV), Caja 229, vol. 321, fol. 62.

${ }^{17}$ Archivo Histórico Provincial de Burgos (AHPB), Sección Protocolos Notariales, Sign. 3.637/2, fol. 300.

${ }^{18}$ El Globo, México, 20 de julio de 1868, Tomo II, n. 388, p. 3.

19 RUEDA HERNANZ, Germán. Los españoles de allá... Op. cit., p. 417.

${ }^{20}$ AHPB. Sección Protocolos Notariales, Sign. 3.641, fols. 647-648. 23 de septiembre de 1869. Al pie del protocolo firmaban, además del matrimonio, el padre de la novia y los testigos José San Román Zaldo y Juan Mingo San Román.

${ }_{21}$ AHPB. Sección Protocolos Notariales, Sign. 3.641, fol. 649. 23 de septiembre de 1869. 
españoles ${ }^{22}$. La prosperidad de Bruno se hizo extensiva tanto a los progenitores del matrimonio como a quienes formaban parte de lo que podemos denominar "clientela parental" generada en torno a su figura. Por señalar algunos nombres, Adolfo Espinosa, Anselmo Román, Mariano Rivera, Gregorio de Benito, Rafael Arana, etcétera, se miraron en su espejo y forjaron una red clientelar que, con un carácter centrífugo, se expandió y fortaleció al menos media centuria ${ }^{23}$.

\section{Consolidación de los negocios y fortuna mexicanos}

La Casa Zaldo Hermanos y Cía. consolidó paulatinamente su negocio y se convirtió en uno de los referentes del sector en el Estado veracruzano, siendo fundadores del Centro Mercantil, una especie de cámara de comercio. La Casa amplió sus secciones con lencería, algodones, lanas o sedas, expandiéndose en la siguiente década con cinco almacenes, estableciendo alianzas en subsectores como el peletero -junto a López Cuesta-, importando hilo, fabricando crinolinas y polisones, o poniendo en marcha fábricas de algodón como San Bruno y La Purísima. Un aspecto trascendente, para entender el crecimiento de su fortuna posterior, fue la intermediación con el objeto de realizar pequeños giros de dinero con al menos 70 ciudades españolas, lo que implicó la primera incursión en lo que, en un interesante salto cualitativo, serán sus futuros establecimientos bancarios ${ }^{24}$.

Estos primeros giros se extendieron a otras operaciones como préstamos, órdenes de pago, hipotecas, etcétera. No hay que olvidar que el último tercio del siglo $\mathrm{XIX}$, representó para México una etapa de progresivo crecimiento económico con posibilidades de inversión ${ }^{25}$. En poco tiempo, los Zaldo lograron configurarse como accionistas del Banco de Londres y México -denominado originalmente como Banco de Londres, México y Sudamérica-, una sucursal del banco inglés The London Bank of Mexico and South America Ltd. No obstante, el punto de inflexión para la Casa Zaldo se produjo al establecer una fecunda alianza con el también peninsular Antonio Basagoiti, fundando en la capital mexicana el banco particular Basagoiti-Zaldo, de fuerte calado potencial, pues financió y participó progresivamente en el desarrollo industrial mexicano. Los Zaldo fueron, igualmente, accionistas del Banco Mercantil Mexicano, desde su fundación en 1882, y del Banco Nacional de México. En este mismo ámbito consiguieron, en 1897, la concesión para establecer el Banco Mercantil de Veracruz -las acciones familiares sobrepasaban el $81 \%$ del total-, el Banco Oriental de México o participar en el Banco de Tabasco ${ }^{26}$.

Al mismo tiempo, aumentó la diversificación de sus empresas, que desembocó en 1899 en la fundación de la Tabacalera Mexicana. Adquirieron ingenios de azúcar y haciendas de café, participaron en compañías ferroviarias y navieras, vapores correo, vapores comerciales, o en la consignación de los vapores trasatlánticos de Pinillos, Izquierdo y Cía. Por último, cabría apuntar que fueron accionistas de otras numerosas

22 CERUTTI PIGNAT, Mario. Españoles y empresariado en el norte de México... Op. cit., p. 18.

${ }^{23}$ MARTÍN GARCÍA, Juan José. Trabajo rural-Trabajo industrial... Op. cit.

${ }^{24}$ Revista de las existencias de ropa de Zaldo Hermanos y Cía. 1 de agosto de 1874, n. 32.

${ }^{25}$ KUNTZ FICKER, Sandra (coord.). Historia económica general de México. De la colonia a nuestros días. México: El Colegio de México; Secretaría de Economía, 2010.

${ }^{26}$ MARICHAL, Carlos. De la Banca privada a la gran banca. Antonio Basagoiti en México y España, 1880-1911. Historia mexicana. 1999, vol. 48, n. 4, pp. 767-793. 
industrias 27 .

\section{El retorno a España. Un nuevo espacio para la diversificación empresarial}

Poco tiempo después de casarse y recorrer Europa en luna de miel, Bruno retornó a España, "fundando en su país natal grandes almacenes de paños", y abriendo en 1873 una casa de banca en Madrid, "en relación con su casa de Veracruz, con la razón social de su nombre que pronto obtuvo, dentro y fuera de la plaza, crédito y prestigio". Entre 1875 y 1879, ya en plena Restauración monárquica, fue adquiriendo notables cantidades de deuda pública, así como bienes desamortizados y fincas rústicas ${ }^{28}$, iniciando la diversificación de sus inversiones y demostrando especial acierto para detectar aquellos sectores de mayor atractivo en un momento decisivo en la industrialización y el desarrollo económico español.

Para ello se apoyó en su experiencia y en la fortuna adquirida en tierras americanas. Un peculio que se vio incrementado, en 1876, gracias a un sustancioso premio obtenido en la Lotería de Navidad -1.570 .000 pesetas-, cuestión tratada ampliamente por la prensa madrileña: "En una de las operaciones de aquella entidad bancaria, el Sr. Zaldo se equivocó, acaso la única vez de su vida en materia de negocios. Uno de ellos, que consideraba desgraciado hizo que se tuviese que quedar a la fuerza la casa con varios billetes de la Lotería Nacional: la suerte le favoreció con el premio mayor"29.

Aunque no fue una circunstancia determinante, esta inyección de capital coadyuvó a implementar sus embrionarias empresas de construcción. Uno de los primeros pasos en este sentido fue la creación, junto al ingeniero Baldomero Santigós, de La Cerámica Madrileña, en el barrio madrileño de Vallecas ${ }^{30}$, para la que obtuvieron licencia en $1877^{31}$. Dos años después, la prensa se hacía eco de la concesión "del privilegio de invención por quince años de un horno continuo para cocer toda clase de objetos de cerámica, cal, yeso, cemento, etcétera", habiéndose verificado una prueba oficial. El resultado fue sumamente satisfactorio para el director y para Zaldo, "socio capitalista que no ha omitido gastos ni sacrificios de todo género". Varios medios les felicitaban y auguraban grandes éxitos por lo moderno de la maquinaria, que podía compararse con las mejores del extranjero. Sus producciones se centraron en tejas, baldosines, ladrillos huecos y para forjado, pero también en productos artísticos y piezas de escultura ${ }^{32}$.

27 CERUTTI PIGNAT, Mario. Empresarios españoles... Op. cit.; MARICHAL, Carlos. Empresarios españoles de ida y vuelta en el México porfiriano y en la España de la restauración. El caso de Antonio Basagoiti y Arteta, 1880-1910. Les Cahiers ALHIM. Amèrique Latine. Histoire \& Mémoire. 2009, n. 17, pp. 149-168. Les Cahiers ALHIM. Amèrique Latine. Histoire \& Mémoire. 2009, n.17, pp. 149-168.

${ }_{28}$ Boletín Oficial de la Provincia de Madrid (BOPM). 26 de noviembre de 1877, p. 3; 13 de noviembre de 1878, p. 3; 29 de noviembre de 1878, p. 1; 12 de noviembre de 1879, p. 3.

${ }^{29}$ Revista llustrada de Banca, Ferrocarriles, Industria y Seguros. 25 de junio de 1910, Tomo XVIII, n. 12, p. 292.

30 LLADOS Y RIUS, Magín. Nueva fábrica en Madrid: la Cerámica Madrileña. Revista Minera. 1880, n. 237, pp. 217-218; BAHAMONDE MAGRO, Ángel y TORO MÉRIDA, Julián. Burguesía, especulación y cuestión social en el Madrid del siglo XIX. Madrid: Siglo Veintiuno de España, 1978, p. 128.

${ }^{31}$ Archivo de la Villa de Madrid (AVM). SEC. 5-194-74.

${ }^{32}$ La Unión. 17 de abril de 1879, Año II, n. 189, p. 3. Dos días después, el mismo texto era reproducido por La lberia. 
La factoría contó con la aprobación de la Sociedad Central de Arquitectos de Madrid ${ }^{33}$, de ahí que muchas obras, en plena expansión urbanística de la capital, utilizaran sus producciones, como la iglesia de la Almudena ${ }^{34}$ o la Ciudad Lineal ${ }^{35}$. Su calidad y buena gestión empresarial hizo que cosecharan galardones en exposiciones industriales, dejando constancia en el diseño de su imagen corporativa ${ }^{36}$. En resumen, el resultado fue exitoso, continuando la extensión de sus instalaciones, y pidiendo, en 1884, la concesión de beneficios como "colonia agrícola", para construir viviendas obreras ${ }^{37}$. Aunque la solicitud fue denegada, la fábrica siguió creciendo, erigiéndose a principios del siglo XX una nueva chimenea y diversificando la producción ${ }^{38}$. Además, para garantizar el suministro de arcillas, logró la concesión de un "ferrocarril minero de vía estrecha", aunque su realización se dilató hasta después de su muerte $^{39}$.

Mientras tanto, Madrid se estaba preparando para acometer un proyecto constructivo de singular envergadura, tanto por el volumen edificatorio como por sus implicaciones urbanísticas: la Cárcel Modelo, presentada a la opinión pública como ejemplo de la moderna política penitenciaria estatal. Entre los distintos proyectos elaborados se eligió el de Tomás Aranguren, nombrado director facultativo de las obras, siendo Eduardo de Adaro el arquitecto auxiliar. En la licitación pública se presentaron siete propuestas, correspondiendo la más ventajosa a Bruno Zaldo y su socio Dionisio de Goyri, quienes se comprometieron a ejecutar la obra en 30 meses y 4.761.215 pesetas ${ }^{40}$. Inaugurada en 1883 , en su realización se emplearon materiales de la citada Cerámica Madrileña, aspecto que demuestra la perspicacia de Zaldo. Las vicisitudes de los trabajos hicieron que su coste superase un $38 \%$ del presupuesto inicial ${ }^{41}$. A pesar de ello, Aranguren se mostró satisfecho de la favorable implicación de Zaldo en el proyecto ${ }^{42}$.

Evidentemente, esta obra le permitió establecer interesantes contactos personales y profesionales, no solo con prebostes de la construcción y las obras públicas, sino con altos miembros de la administración central y local, capitalistas financieros y representantes del mundo técnico y la arquitectura madrileños. Por otro lado, el elevado importe de los trabajos hizo que el Gobierno no tuviera liquidez suficiente a la hora de cerrar los pagos convenidos, arbitrándose otras fórmulas que le fueron muy ventajosas ${ }^{43}$.

\footnotetext{
${ }^{33}$ Revista de la Sociedad Central de Arquitectos. 10 de julio de 1882, p. 4.

34 La Correspondencia de España. 13 de marzo de 1882, Año XXXIII, n. 8.756, p. 4.

35 La Ciudad Lineal. 20 de noviembre de 1911, n. 467, p. 2923; 30 de enero de 1912, n. 474, p. 39.

${ }^{36}$ Archivo del Museo Sorolla. Sign. CS6656, Factura de la Cerámica Madrileña.

37 PANIAGUA MAZORRA, Ángel. Catálogo de colonias agrícolas históricas de la Comunidad de Madrid 1850-1980. Madrid: Instituto de Economía y Geografía, 2005, pp. 103-105.

${ }^{38}$ AVM. SEC. 23-280-39.

39 ALBERICH GONZÁLEZ, Joan. El ferrocarril de la Cerámica Madrileña. Revista de Historia Ferroviaria. 2017, n. 19, pp. 7-17.

40 Guía Oficial de España. 1878, p. 702.

${ }^{41}$ Revista contemporánea. Nov.-dic. 1883, Año IX, Tomo XLVIII, 11/1883, pp. 241-242.

${ }^{42}$ Archivo de la Ciudad de Arganda del Rey, (ACAR). Fondo Histórico, C0.01.00. Minuta de la liquidación general realizada tras la construcción de la Cárcel Modelo de Madrid. Fondo: "Arquitecto Aranguren".

${ }^{43}$ Archivo Histórico de Protocolos de Madrid (AHPM). Tomo 35.526, fols. 840-851.
} 
Mientras esto sucedía, el 8 de julio de 1882 nuestro protagonista constituyó la Sociedad Ponos S.A. en compañía del arquitecto Tomás Aranguren, Mariano Monasterio y Antonio de Sagarminaga, y junto con los hermanos Francisco y Bernardo Forzano y Palenzona. Estos últimos habían inventado "un procedimiento de planchas huecas, aplicables a la construcción de muros interiores y exteriores de edificios y bovedillas para pisos", consiguiendo la patente cuyos derechos pasaron a la sociedad $^{44}$. Fruto del conocimiento que iba adquiriendo sobre las posibilidades de los productos cerámicos, Zaldo se incorporó al mundo de la fabricación de loza a través de la fábrica La Constancia. En febrero de 1889 firmaba una escritura de fusión con las instalaciones de Falcó, Peña y Cía., situadas en Valdemorillo ${ }^{45}$ y, nueve años más tarde, adquiría de Consuelo Falcó la octava parte de la fábrica ${ }^{46}$.

En relación con estas operaciones, en 1903 estableció otra sociedad en la que también participaron los Falcó, denominada Electro-hidráulica de la Aldehuela, cuya firma sería Zaldo, Arana y Cía, para explotar los saltos de agua del Tajo. Bruno y su pariente y paisano, Rafael Arana, serían los administradores generales. El inventario de bienes y derechos ascendía a la considerable cantidad de 625.000 pesetas $^{47}$. Su objetivo era producir energía eléctrica para una extensa zona del sur madrileño. Así, en 1903, se obligaban con el Ayuntamiento de Villaconejos para hacerse cargo de su alumbrado público ${ }^{48}$. Por último, entre otras, también participó en la sociedad azufrera del coto de Hellín y en la Sociedad Alcoholera Española, de la que fue socio fundador y accionista ${ }^{49}$.

Si bien es relevante el engranaje industrial visto hasta el momento, será la fundación del Banco Hispano Americano la que elevará a Bruno Zaldo a desempeñar un papel protagónico como empresario contemporáneo, al ser esta una de las instituciones financieras más destacadas del siglo XX español. Amparados en la experiencia mexicana, la idea de crear este banco se fraguó el 16 de junio de 1900, en una reunión celebrada en el domicilio del citado Antonio Basagoiti, en la cual se leyó un proyecto de bases redactado por ellos mismos, junto con Luis Ibáñez y Florencio Rodríguez. En él se nombró un Consejo de Administración provisional que, a su vez, estableció dos comisiones con el fin de repartir los trabajos necesarios para la implantación de la sede, situada en un principio en la céntrica calle madrileña de Alcalá 50 .

\footnotetext{
${ }^{44}$ BOPM. 28 de julio de 1882, pp. 1-4.

45 PERLA, Antonio. La iniciativa industrial y artística en la porcelana y la cerámica madrileña del siglo XIX desde 1808: La Moncloa, Valdemorillo, Vallecas, los Zuluaga, etc. En: COLL CONESA, Jaume (coord.). Manual de cerámica medieval y moderna. Alcalá de Henares: Museo Arqueológico Regional, 2011, pp. 231-270; SIERRA ÁLVAREZ, José y TUDA RODRÍGUEZ, Isabel. Las lozas de Valdemorillo: una aportación a la historia de las artes industriales madrileñas, (1845-1915). Madrid: Consejería de Educación y Cultura, 1996.

${ }^{46}$ AHPM. Tomo 40053, fols. 667-678.

${ }^{47}$ AHPM. Tomo 41.224, fols. 1.053-1.079.

${ }^{48}$ Archivo Regional de Madrid. Sign. 17720/1342.

${ }^{49}$ Revista llustrada de Banca, Ferrocarriles, Industria y Seguros. 25 de junio de 1910, Tomo XVIII, n. 12, p. 292.

${ }^{50}$ Banco Hispano Americano. El primer medio siglo de su historia. Madrid. Impr. Maestre, 1951, pp. 1130.
} 
Poco después, el 25 de octubre, se protocolizó la escritura de constitución bajo la forma de compañía mercantil, redactándose sus estatutos al objeto de iniciar las operaciones el 1 de enero de 1901, con un capital de 100 millones de pesetas. Su planteamiento prioritario era "fundar en esta corte una Sociedad de Crédito que sea el producto de unión de los intereses mercantiles e industriales de España y las repúblicas del Centro y Sur de América [...] acrecentando por cuantos medios estén a su alcance las corrientes de unión y simpatía que, por fortuna, existen entre la madre patria y sus antiguas colonias". El banco tendría en Madrid su domicilio social y, para la mejor consecución de sus fines, establecería sucursales en las más importantes ciudades de América, España y resto del mundo. En principio, la duración de la sociedad sería de 50 años y el capital se dividiría en 200.000 acciones de 500 pesetas. Cada uno de los miembros de la Junta General tendría un voto por cada 20 acciones y solo podrían ser consejeros aquellos que poseyesen $500^{51}$.

En el primer Consejo, presidido por Basagoiti, Bruno Zaldo figuró como vicepresidente y su hermano Gervasio como vocal noveno. Sin embargo, los posteriores consejos, hasta mayo de 1903, los encabezaría Zaldo, ya que Basagoiti emprendió un viaje de expansión comercial por distintos países de América ${ }^{52}$. Por ello fue el responsable de su puesta en marcha, incluida la construcción de la sede, para la que se adquirieron amplios terrenos en la Plaza Canalejas ${ }^{53}$, abriendo las oficinas el 20 de noviembre de 1905.

Por todo lo dicho, se evidencia la dificultad de resumir el enorme bagaje para la estructuración de la fortuna familiar de Bruno Zaldo, extensa en el tiempo, variada en la tipología de sus sectores y profunda por su capacidad de trabajo y gestión. En este sentido, es muy significativo que, hacia 1905, el antiguo emigrante que salió de Pradoluengo hasta Veracruz siendo prácticamente un niño, debiera pagar anualmente 3.162 pesetas por contribución industrial y 984 por territorial, o que, en 1910, figurase como el 28 mayor contribuyente de Madrid, pagando 12.632 pesetas ${ }^{54}$.

\section{Vida social y política en el Madrid de la Restauración}

En relación con el carácter inevitablemente poliédrico de una personalidad como la de Bruno Zaldo, su presencia en la vida pública tuvo facetas que evidenciaron múltiples intereses, al tiempo que contribuyeron a construir su imagen, siendo complicado incluir sus actuaciones en categorías excluyentes. Tras su instalación en Madrid, y de forma progresiva, se fue haciendo un hueco en la vida social de la Corte, hasta convertirse en un personaje recurrente de la misma.

Gran parte de estas actividades mostraron un claro componente económico, al integrarse, fundamentalmente a partir de 1880, en sociedades e instituciones cuyos objetivos pretendían el progreso del país. Así, fue socio de la Sociedad Económica

\footnotetext{
51 AHPM. Tomo 40.408, fols. 1.942-1.965.

52 Banco Hispano Americano... Op. cit., pp. 11-30.

53 AMV. SEC. Contaduría 5-514-3.

${ }^{54}$ El Imparcial. 4 de abril de 1910, Año XLIV, n.15.471, p. 4.
} 
Matritense ${ }^{55}$, y síndico del Círculo de la Unión Mercantiß6, colaborando de forma activa y generosa en las expediciones organizadas por la Sociedad Española de Africanistas y Colonialistas, impulsada por Joaquín Costa ${ }^{57}$.

Por otro lado, tuvo preocupaciones de carácter eminentemente socio-cultural, como demuestra que fuera miembro del elegante Ateneo Científico y Literario $^{58}$, interesándose por agrupaciones que también conjugaban en su seno las relaciones económicas, como la Unión Ibero-Americana, de la que fue socio fundador y directivo ${ }^{59}$. Puesta en marcha en 1885 , se fusionó, cinco años más tarde, con la Unión Hispano-Americana, siendo sus objetivos estrechar lazos culturales, científicos y económicos entre España y América ${ }^{60}$.

Estos círculos le abrieron un amplio abanico de contactos, convirtiéndose en apoyo imprescindible para sus negocios y le otorgaron la conveniente visibilidad pública. Esta quedaba reforzada por su asidua participación en homenajes y banquetes honoríficos. Su presencia resultaba imprescindible si el agasajado procedía de Ultramar, como durante la visita en 1906 del ministro de Hacienda mexicano, siendo uno de los pocos invitados al almuerzo ofrecido por el presidente del Consejo de Ministros, Segismundo Moret ${ }^{61}$.

No obstante, este tipo de actos, aunque minuciosamente recogidos por la prensa, y de especial significación para el mundo de los negocios, no tenían tanto eco en la construcción de su imagen social como los de carácter lúdico: la renovación de su abono del Teatro Real, la salida de vacaciones a lugares de moda como París o San Sebastián -donde adquirió una vivienda-, los elegantes balnearios, o su asistencia a la corrida de la prensa, novilladas benéficas o cacerías, le permitían compartir protagonismo en las páginas de revistas con personajes "harto conocidos en la buena sociedad madrileña"62. Así sucedió, igualmente, con los agasajos preparados en Madrid con motivo del enlace matrimonial entre Alfonso XIII y Victoria Eugenia, en los que participó junto con sus hijos ${ }^{63}$.

En sus pautas sociales no podían faltar rasgos propios de su mentalidad cuasi clánica, según hemos comprobado en otras facetas de su vida. En este sentido, hay un hecho que parece entroncar más con las pautas de la vieja nobleza que con una actitud moderna, pero que, en cualquier caso, explica el deseo de conservar el núcleo de la fortuna en el entorno familiar. Nos referimos a la boda de su hija Isaura con su hermano Gervasio, por tanto, tío carnal de la novia. El Heraldo de Madrid daba noticia del enlace de "la distinguida señorita doña Isaura Zaldo y Arana, hija del opulento

\footnotetext{
${ }^{55}$ Diario oficial de avisos de Madrid. 7 de julio de 1882, p. 3.

${ }^{56}$ El Día. 31 de mayo de 1882, p. 2.

57 El Imparcial, 13 de junio de 1884, p. 2.

58 El Heraldo de Madrid. 14 de junio de 1907, p. 5.

59 La Correspondencia de España. 12 de febrero de 1885, p. 2.

60 SEPÚLVEDA MUÑOZ, Isidro. Medio siglo de asociacionismo americanista español. Espacio, Tiempo

y Forma, Historia Contemporánea. 1991, n. 4, pp. 271-290.

61 El Globo. 8 de junio de 1906, p. 2.

62 La Correspondencia de España. 13 de noviembre de 1902, p. 3.

${ }^{63}$ El Liberal. 29 de mayo de 1906, p. 3 y La Correspondencia de España. 6 de junio de 1906, p. 2.
} 
banquero D. Bruno Zaldo"64. La actitud centrípeta adoptada con Isaura se corroboró con su otra hija, Victoria, quien, en 1902, contraía matrimonio con otro pradoluenguino, Adolfo Espinosa, avalando los invitados a la boda los fuertes lazos de apadrinamiento y clientelismo parentelar ${ }^{65}$. Sin embargo, con su hijo varón, Vicente, se apartó de esta línea de comportamiento, pues, en 1905, casaba con Amada Muriedas, elegante joven de la sociedad madrileña, en la iglesia del Sagrado Corazón ${ }^{66}$. Por parte de la novia asistió como testigo el diputado conde de Garay quien, un año más tarde, casaba con Nicasia Herreros, viuda de un hermano de Bruno ${ }^{67}$.

No obstante, su proactividad miraba más al futuro que al pasado. Así, si bien hubiera podido conseguir sin grandes trabas el respaldo de un título nobiliario, a diferencia de otros personajes paralelos que sancionaron su fortuna con estas distinciones -como el marqués de Comillas, el duque de Santoña, etc.- ${ }^{68}$, Zaldo no fijó sus metas en tales oropeles. En todo caso, lo hizo en otros cargos más prácticos, interviniendo en política -primero en una dimensión local, después, nacional-, al objeto de consolidar su estatus. No obstante, al tiempo que la ejerció sin grandes alardes ideológicos, su adscripción a los liberales de Martínez del Campo se basaba no solo en raíces de paisanaje -los orígenes de este último se encontraban en Pradoluengo y el cercano Belorado- sino que presentaba matices de pensamiento ${ }^{69}$.

En el Ayuntamiento de Madrid fue vocal de la junta municipal al menos entre 1889 y $1908^{70}$, formando parte de la comisión de ensanches ${ }^{71}$. En 1905 fue elegido diputado por Madrid, apoyado en su posición económica y popularidad, defendiendo disminuir el paro obrero y enarbolando varias propuestas realmente ambiciosas que serían fuente de prosperidad generalizada, como la construcción de una Alhóndiga-modelo, la organización de una Exposición lberoamericana o la apertura de la necesaria Gran Vía ${ }^{72}$. Se mostró dispuesto a contribuir personalmente en esta última iniciativa, que beneficiaba directamente a su distrito y, sin duda, también a quienes, como él, tenían intereses en la construcción ${ }^{73}$.

En 1907 volvió a presentarse con el apoyo expreso de José Canalejas, siendo reelegido, aunque renunció para tomar posesión como senador por la provincia de Burgos, vacante por defunción de Manuel de la Cuesta. También en 1907 recibió la Gran Cruz de Isabel la Católica, única distinción que ostentó y de la que se mostró especialmente orgulloso. Tres años más tarde, formó parte de la candidatura monárquica ${ }^{74}$, elecciones en las que el escritor Benito Pérez Galdós obtuvo 42.233 votos, el fundador del Partido Socialista Obrero Español, Pablo Iglesias, 40.925 y,

${ }^{64}$ El Heraldo de Madrid. 10 de diciembre de 1893, Año IV, n. 1.132, p. 3.

65 La Correspondencia de España. 19 de octubre de 1902, Año LIII, n. 16.326, p. 3.

66 La Correspondencia de España. 28 de febrero de 1905, p. 2.

67 La Época. 1 de febrero de 1906, p. 2.

68 SAZATORNIL RUIZ, Luis. Arte y mecenazgo... Op. cit., pp. 543-612.

69 CARASA SOTO, Pedro (dir.). Élites castellanas de la Restauración. Diccionario biográfico de parlamentarios castellanos y leoneses (1876-1923). Valladolid: Junta de Castilla y León, 1997, p. 558.

70 La Correspondencia de España. 30 de noviembre de 1889, p. 3; La Época, 28 de julio de 1894, p. 4; etcétera.

${ }^{71}$ La Correspondencia de España. 23 de mayo de 1903, p. 2.

72 La Época. 9 de septiembre de 1905, p. 2 y Nuevo Mundo. 11 de septiembre de 1905, pp. 1 y 2.

${ }^{73}$ La Época. 2 de marzo de 1906, n. 19.965, p. 3.

${ }^{74}$ Archivo del Congreso de los Diputados, Serial documentación electoral: 119, n. 29 y 123, n. 29. 
Bruno Zaldo, 31.61275.

\section{Saber de dónde se viene: el espíritu filantrópico}

La inmensa mayoría de aquellos que emigraron a América y lograron un enriquecimiento rápido y considerable, buscaron demostrar su triunfo ante sus paisanos. Además de la propia ostentación, no solo en bienes muebles e inmuebles, del ascenso en la escala social, y del posicionamiento en las más altas esferas de decisión, un elemento que definió la figura de Zaldo fue su espíritu filantrópico ${ }^{76}$. Esta característica le acompañó desde primera hora hasta más allá de su muerte, quizá por tener asumida, de forma latente, su procedencia humilde, y conocer las dificultades que acechaban a los miembros de las capas menos favorecidas.

En este sentido, siempre tuvo presente su patria chica. Proporcionalmente, fue la que más se benefició de sus dádivas. Lo demostró muy pronto, tras uno de sus viajes por Europa en 1869: "Convencido hace tiempo de la necesidad en que este mi pueblo natal se encuentra de proveerse de una bomba contra incendios [...], en mi última permanencia en París de Francia, encargué la construcción de una bomba sistema Foulante número 2, último modelo adoptado en el mismo París". El donativo lo hacía "como una pequeña muestra del profundo amor que siempre he conservado en mi corazón hacia el pueblo que me vio nacer, cuyos intereses, deseando caminen por la senda del progreso bien entendido, quisiera verlos conservados y exentos de los riesgos de un incendio"77.

Las obras de caridad y donaciones filantrópicas fueron seña de identidad de los hermanos Zaldo desde sus inicios comerciales en Veracruz. En 1869 contribuían a su fondo de seguridad ${ }^{78}$, un año después entregaban una aportación al Hospicio veracruzano $^{79}$ y, en 1871 , donativos para su biblioteca, museo y archivo, siendo vocales, en 1873, de su Real Junta de Caridad ${ }^{80}$.

Ya asentado en Madrid, Bruno potenció esta dimensión, tan diversificada como sus propios negocios, dirigida con preferencia -como era habitual entre los indianoshacia la sanidad y la educación, y siempre desde presupuestos innovadores hacia los que era especialmente receptivo, dada su propia capacidad personal para el cambio ${ }^{81}$. Prueba de ello, en 1877 donaba 10.000 reales para la Sociedad Hahnemanniana matritense, al objeto de fundar y mantener un hospital homeopático. Era la cifra más elevada tras la de la reina madre, Doña Isabel de Borbón ${ }^{82}$. Su preocupación por los temas médicos le hizo ser, a su vez, miembro de la Junta de la Sociedad Española de

\footnotetext{
75 La Correspondencia de España. 10 de mayo de 1910, Año LXI, n. 19.081, n. 17.523, p. 1.

${ }^{76}$ ARAMBURU-ZABALA HIGUERA, Miguel Ángel y SOLDEVILLA ORIA, Consuelo. Arquitectura de los indianos en Cantabria... Op. cit., p. 59; PALIZA MONDUATE, M. ${ }^{a}$ Teresa. El mecenazgo de los indianos... Op. cit., pp. 435-460.

77 Archivo Municipal de Pradoluengo (AMP). Sign. 171, 10 de noviembre de 1869.

${ }^{78}$ AHMV. Caja 229, vol. 321, fol. 62.

${ }^{79}$ AHMV. Caja 240, fol. 542.

${ }^{80}$ AHMV. Libro 16, fol. 162.

${ }^{81}$ ARAMBURU-ZABALA HIGUERA, Miguel Ángel y SOLDEVILLA ORIA, Consuelo. Arquitectura de los indianos en Cantabria... Op. cit., p. 59

${ }_{82}$ El criterio médico. 25 de abril de 1877, Año XXIX, Tomo XVIII, n. 9, p. 192.
} 
Higiene ${ }^{83}$. Por otro lado, su interés por los proyectos de carácter educativo le convirtió en accionista de la Institución Libre de Enseñanza, de cuya directiva formó parte en 1882, lo cual le permitió establecer contactos con algunos de los más destacados intelectuales del país, o le llevó a colaborar con importantes dádivas en la construcción de grupos escolares ${ }^{84}$.

Otros rasgos fueron puramente caritativos, atendiendo necesidades urgentes provocadas por alguna catástrofe o intentando socorrer a los menos favorecidos. En 1885 participaba en la suscripción nacional contra las inundaciones en Valencia y Andalucía, entregando también al rey Alfonso XII, por cuenta de Zaldo Hermanos y Cía -todavía domiciliada en Veracruz-, 40.000 pesetas para mitigar los desastres de los terremotos de Málaga y Granada ${ }^{85}$. Un año después, contribuía junto a la alta sociedad de la Corte en la creación de su tercera tienda-asilo ${ }^{86}$. Sin duda, estas actuaciones se vieron influidas por la doctrina del catolicismo social, como lo prueba su continuado apoyo a la Revista Católica de las Cuestiones Sociales, de la que fue protector benemérito ${ }^{87}$.

La panoplia de donativos, cuestaciones, suscripciones, proyectos sociales y demás limosnas caracterizaron las actuaciones de Zaldo y su familia, aunque, a la par que generosas, no fueron totalmente desinteresadas. Estas muestras caritativas le permitieron abrir y consolidar su círculo de contactos y conocidos de las altas esferas, así como la construcción de su figura como la de un "buen patrón" preocupado por sus obreros. En este sentido, en 1889, aparecía como tesorero de la Sociedad Central de Arquitectos, que estaba poniendo en marcha el Consejo Superior protector de los albañiles, cuya pretensión final era establecer montepíos por todo el país ${ }^{88}$. Así mismo, sostenía en Madrid el Asilo de Nuestra Señora de la Asunción, destinado a "proteger y educar a los hijos de los obreros muertos e inutilizados en la construcción de casas" 89 . Tuvo especial sensibilidad hacia las necesidades infantiles, entregando dinero, entre otras, a la Sociedad Protectora de los Niños o al Hospital de Niños Incurables ${ }^{90}$.

A esta ingente labor social hay que unir la que será, sin duda, una de sus obras filantrópicas de mayor calado: la construcción y mantenimiento en su localidad natal del Hospital Asilo de San Dionisio. La idea original partió de su hermano Dionisio, quien, desde su testamento en 1874-27 años antes de la fecha de su inauguraciónya legaba la tercera parte de sus bienes para la fundación de un hospital de caridad, nombrando responsables a su padre y hermanos. Esta idea, con cambios nimios, la corroboró en 1878 y 1884, y la hizo suya Bruno ${ }^{91}$. En 1899 se concedía el permiso para su construcción ${ }^{92}$, no parando en su afán por mejorar las condiciones de sus

\footnotetext{
${ }^{83}$ La lberia. 13 de octubre de 1883 , p. 3.

84 La Discusión. 29 de mayo de 1882, p. 3.

85 La Época. 7 de febrero de 1885, Año XXXVII, n.11.698, p. 2.

${ }^{86}$ El Día. 3 de mayo de 1886, n. 2.152, p. 2.

87 Revista católica de las cuestiones sociales. 4 de enero de 1905, p. 2.

${ }^{88}$ El Día. 7 de julio de 1889 , n. 3.299, p. 2.

${ }^{89}$ Revista llustrada de banca, ferrocarriles, industria y seguros. 10 de julio de 1897, p. 1.

90 El mundo de los niños. 20 de diciembre de 1890, p. 559.

${ }^{91}$ AHPB. Sección Protocolos Notariales, Sign. 11.008, fols. 224-232, 13 de septiembre de 1896.

92 AMP. Sign. 174, 30 de junio de 1899.
} 
paisanos. Una prueba fueron sus gestiones para que, en 1907, se enviase una biblioteca popular desde el Ministerio de Instrucción Pública93. No es extraño que estas donaciones le reportasen magníficos recibimientos en Pradoluengo: "teniendo en cuenta los servicios prestados a la localidad por el hijo de este pueblo el Senador del Reino Don Bruno Zaldo, y al celo e interés que atiende cuanto contribuye al bienestar del mismo, se acuerda que en la primera vez que venga a esta población salga la Corporación a recibirlo con la solemnidad posible para demostrarle el afecto que se le profesa"94.

\section{Un aspecto clave de sus negocios: la promoción inmobiliaria}

Si volvemos la mirada a la participación de Bruno en La Cerámica Madrileña, comprobaremos su trascendencia, ya que supo conjugar su vertiente puramente productiva con el contexto expansivo que vivía el Madrid de la Restauración mediante el "Plan Castro" o Ensanche de Madrid. Este plan permitió acometer un fuerte proceso de renovación y crecimiento urbano, lo que convirtió la promoción inmobiliaria en un próspero negocio ${ }^{95}$.

A través de diversos mecanismos, Zaldo logró acaparar solares de gran potencial. Algunos fueron consecuencia del pago de la señalada contrata de la Cárcel Modelo, como la antigua cárcel de la Villa o del Saladero, que derribó para obtener espacios situados en uno de los puntos estratégicos del ensanche madrileño, la Plaza de Santa Bárbara, inmediata a la actual Plaza de Alonso Martínez. También en pago de saldos por la citada contrata, consiguió terrenos públicos apetecibles para la ejecución de posteriores proyectos en el entorno de Atocha96, arranque del Ensanche Sur ${ }^{97}$.

Estas cesiones incrementaron sus propiedades al menos desde 1877. Ese año participó en una subasta de siete solares de la manzana $F$ del Buen Retiro, en las cercanías del Salón del Prado, quedándose con cuatro. La zona se convertiría en pieza codiciada de la capital ${ }^{98}$, logrando hacerse, también, con parcelas en la manzana $G$ o en el elitista Barrio de Salamanca ${ }^{99}$. Igualmente, compró una amplia extensión de terrenos edificables en la zona de Moncloa, parte de los cuales vendería en fases a la fábrica de cervezas y gaseosas El Laurel de Baco ${ }^{100}$. En otras ocasiones,

\footnotetext{
${ }^{93}$ AMP. Sign. 179, fol. 5 vuelto, 22 de febrero de 1907.

${ }^{4}$ AMP. Sign. 180, fol. 9 vuelto, s.f. 1908.

95 CARBALLO, Borja; PALLOL, Rubén y VICENTE, Fernando. El Ensanche de Madrid. Historia de una capital. Madrid: Editorial Complutense, 2008.

96 AHPM. Tomo 35.526, fols. 840-851.

97 Sobre esta zona del ensanche madrileño: VICENTE ALBARRÁN, Fernando. Los barrios negros: el Ensanche Sur en la formación del moderno Madrid (1860-1931) [tesis doctoral]. Madrid: Universidad Complutense de Madrid, 2011.

98 El Retiro y el Barrio de Salamanca conforman el conocido como Ensanche Este de Madrid, incluidos en el plan diseñado por Castro, en 1860, como una de las tres grandes zonas de expansión de la capital: CABALLERO BARRAL, Borja. El Madrid burgués: el ensanche Este de la capital, (1860-1931) [tesis doctoral]. Madrid: Universidad Complutense de Madrid, 2015.

99 La lberia. 21 de noviembre de 1877, Año XXIV, n. 6.455, p. 3.

100 AHPM. Tomo 40065, fols. 2966-2982; Tomo 40163, fols. 3862-3871; Tomo 40780, fols $976-990$ y Tomo 41102, fols. 689-700.
} 
le encontramos inmerso en permutas con el Ayuntamiento de Madrid en la Glorieta de Delicias, distrito de enorme potencial ${ }^{101}$.

Este patrimonio se convirtió en un interesante activo aprovechado por Zaldo mediante diferentes vías que, hasta ahora, eran desconocidas. Gran parte de estos espacios se encontraban en sectores pendientes de urbanizar y sin alineaciones. Por ello, no era extraño que fuera indemnizado por las expropiaciones ${ }^{102}$. Las cantidades obtenidas por este procedimiento fueron sustanciosas, como evidencia el caso de los terrenos de la cárcel del Saladero, que terminaron constituyendo un escándalo para la prensa más combativa, la cual vio trato de favor hacia Zaldo ${ }^{103}$.

Por otra parte, su participación en el Ayuntamiento en la Comisión del Ensanche le permitió tener una posición privilegiada para velar por sus intereses, lo que reforzó al ser miembro de la directiva de la Asociación de propietarios, comerciantes e industriales de la tercera zona del Ensanche ${ }^{104}$. En este sentido, siempre estuvo atento a mejorar las condiciones de sus propiedades con el fin de conseguir que fueran más atractivas, bien antes de construir en ellas o una vez ya edificadas y alquiladas. Así, en 1886, los propietarios e industriales con intereses en el Barrio de las Peñuelas y Delicias, formaron una comisión para gestionar ante el Ayuntamiento el establecimiento de tranvías que permitieran a esas zonas tener una comunicación más fluida ${ }^{105}$.

El caso más evidente y polémico fue el de la Estación del Mediodía, actual Atocha. Su articulación con el diseño viario afectaba a terrenos de Bruno, quien pidió por ellos un elevado precio, pues quería que la Compañía ferroviaria cambiara el trazado de la entonces denominada Calle del Sur -hoy Méndez Álvaro-, y, de este modo, conservar un solar que tendría fachadas hacia la nueva estación y el Hospital General. Según publicó La Monarquía, el 2 de septiembre de 1888, la contrapropuesta de Zaldo fue aceptada por el Ayuntamiento, primando el interés particular sobre el colectivo. Con respecto a esta misma zona, en 1898, ofreció regalar un tercio de uno de sus solares, siempre que el Ayuntamiento y la Compañía de ferrocarriles aceptasen adquirir los otros dos y destinarlos al trazado de un jardín que mejorase el arranque de la Calle Méndez Álvaro y la convirtiese en un sector atractivo, pudiendo llevarse a cabo edificaciones de otras características menos modestas, lo cual revalorizaría las propiedades, incluidas las suyas ${ }^{106}$.

La construcción de las viviendas que promocionó varió en función del emplazamiento. Esta actividad la concentró, fundamentalmente, en la década de 1880 y en su mayoría fueron confiadas al arquitecto José Asensio Berdiguer ${ }^{107}$, quien ya

\footnotetext{
101 AHPM. Tomo 35526, fols, 840-851 y Tomo 35526, fols. 1313-1369 y AVM, SEC. 6-386-48.

102 AHPM. Tomo 35526, fols. 840-851; Tomo 35526, fols. 1313-1369; AVM. SEC. 18-461-3 y 17-3-7.

103 La República. 20 de agosto de 1886, p. 1; El Motín. 24 de julio de 1887, p. 3; La Época. 4 de agosto de 1889, p. 1; etcétera.

104 La Época. 11 de febrero de 1912, p. 3.

105 El Día. 22 de febrero de 1886, p. 1.

${ }^{106}$ AMV. SEC.18-461-3.

107 CHAVES MARTíN, Miguel Ángel. Arquitectura y urbanismo en la ciudad de Segovia (1750-1950). Segovia: Cámara de la Propiedad Urbana de Segovia, 1998, pp. 152-155.
} 
veló por sus intereses en su época de contratista de la Cárcel-Modelo ${ }^{108}$. En 1882 le encargó, junto con su ya conocido Eduardo de Adaro, la construcción de viviendas en la Calle Juan de Mena, 11-13. Los siguientes proyectos se centraron en sus solares del arranque del Ensanche Sur, donde encomendó a Berdiguer la realización de obras que se adaptasen a las características exigidas, según se destinasen a familias de clase media o proletaria. De ahí las variaciones en materiales, distribución interior y tratamiento de fachadas, lo que revirtió en las condiciones y cuantía de los respectivos alquileres $^{109}$.

A partir de 1889 trabajó con otros arquitectos en zonas privilegiadas de Madrid. Ese año encomendó a Juan Bautista Lázaro el diseño de un elegante inmueble en la calle Juan de Mena, esquina con Alfonso XI y, en 1890, encargó a Francisco Andrés Octavio el proyecto para una casa en Claudio Coello que, finalmente, llevaría a cabo Pedro Domingo Ayerdi, según figura en el permiso para su alquiler ${ }^{110}$. La última promoción de la que tenemos constancia es el palacete que Eduardo de Adaro le erigió en Alfonso XII ${ }^{111}$.

\section{Arte y poder}

Otros proyectos rebasan la mera promoción inmobiliaria para adentrar a Bruno Zaldo en el complejo mundo de las relaciones entre arte y poder, hasta ahora inexploradas y que fue cultivando al mismo tiempo que iba puliendo su imagen social, como elemento necesario para ello en un ciclo de estrecha interdependencia que se retroalimenta. Como otras personalidades paralelas, algunas tan conocidas como los marqueses de Comillas o el duque de Santoña ${ }^{112}$, apoyó la construcción de su imagen pública no solo mediante actuaciones filantrópicas y de sociedad, sino recurriendo a las posibilidades que ofrecían diferentes manifestaciones artísticas que le permitiesen evidenciar, de forma duradera y pública, su nueva posición. Siguiendo pautas de comportamiento intangibles, pero ampliamente reconocidas y aceptadas, nuestro protagonista se centró con preferencia en los proyectos arquitectónicos, lo cual resultaba obligado en alguien tan ligado a la construcción.

En una fecha temprana, 1878, costeó una réplica a tamaño real del extraordinario mirhab de la mezquita de Córdoba, para destinarla a la Exposición Universal de París. El trabajo fue obra del artista José Botana, bajo la dirección de Francisco Contreras, gran conocedor de la arquitectura islámica y a quien se debieron los diseños ${ }^{113}$. También intervinieron los hermanos Zuloaga. Uno de ellos proporcionó el dibujo que

\footnotetext{
108 ACAR. Fondo Histórico, C0.01.00. Minuta de la liquidación general realizada tras la construcción de la Cárcel Modelo de Madrid. Fondo: "Arquitecto Aranguren".

${ }_{109}$ AMV. SEC. 18-461-3; 7-77-50; 7-123-16; etcétera.

110 AMV. SEC. 8-40-50; 9-284-93.

111 NAVASCUES PALACIO, Pedro. Arquitectura y arquitectos madrileños del siglo XIX. Madrid: Instituto de Estudios Madrileños, 1973, p. 277.

112 SAZATORNIL RUIZ, Luis (ed.). Arte y mecenazgo indiano... Op. cit..

113 Sobre Contreras puede consultarse: NAVASCUÉS PALACIO, Pedro. Los autores: arquitectos, pintores y dibujantes. En: ALMAGRO GORBEA, Antonio (ed.). El legado de al-Ándalus. Las Antigüedades árabes en los dibujos de la Academia. Madrid: Real Academia de Bellas Artes San Fernando, 2015, pp. 63-79.
} 
inmortalizó la pieza en la prensa, y con él, la activa participación de Zaldo ${ }^{114}$. Su ejecución debe enmarcarse en los gustos orientalizantes de la época, que trajeron consigo la revalorización de este arte, como se puso de manifiesto en las restauraciones de la mezquita de Córdoba y la Alhambra de Granada ${ }^{115}$, iniciadas cuatro años después, y su utilización como seña de identidad nacional116.

Aunque no consta, es posible que algunos de sus elementos pudieran ejecutarse en La Cerámica Madrileña ${ }^{117}$, constituyendo, en cualquier caso, un excelente reclamo publicitario para la fábrica. Este fue el objetivo de algunas de las instalaciones que realizó la empresa en diversos certámenes, donde se armonizaba técnica y arte para obtener significativos resultados. Así sucedió en la Exposición Nacional de Minería y Artes Metalúrgicas, celebrada en $1883^{118}$ o la de Industrias Madrileñas de 1907, en la que el destacado arquitecto José López Sallaberry efectuó una atrevida instalación en forma de paraguas abierto ${ }^{119}$.

La relación que Zaldo estableció con la arquitectura fue especialmente significativa, adoptando diferenciados matices a medida que su posición en Madrid se iba consolidando. Cuando llegó a la capital, se domicilió en un moderno edificio de la calle de Fuencarral ${ }^{120}$, pero, en 1885 , ya residía en Juan de Mena, en las inmediaciones del Retiro, su primera promoción inmobiliaria; un proyecto cuidado en fachadas, materiales y repertorio decorativo. A esta residencia debió de corresponder el programa diseñado por el pintor bilbaíno Roberto Laplaza, uno de los decoradores de las residencias más elegantes del momento, entre las que la prensa madrileña incluyó la de Zaldo ${ }^{121}$.

Resulta revelador que esta obra no se la confiara solo a Berdiguer, sino también a Eduardo de Adaro, cuyo prestigio había crecido en los círculos de la alta sociedad madrileña ${ }^{122}$. Los hechos posteriores parecen confirmar que, mientras al primero le encargó aquellas obras destinadas a las clases medias u obreras, al segundo -junto con Juan Bautista Lázaro, quien por entonces culminaba la restauración de la Catedral de León- le reservó para los proyectos de mayor impacto ${ }^{123}$.

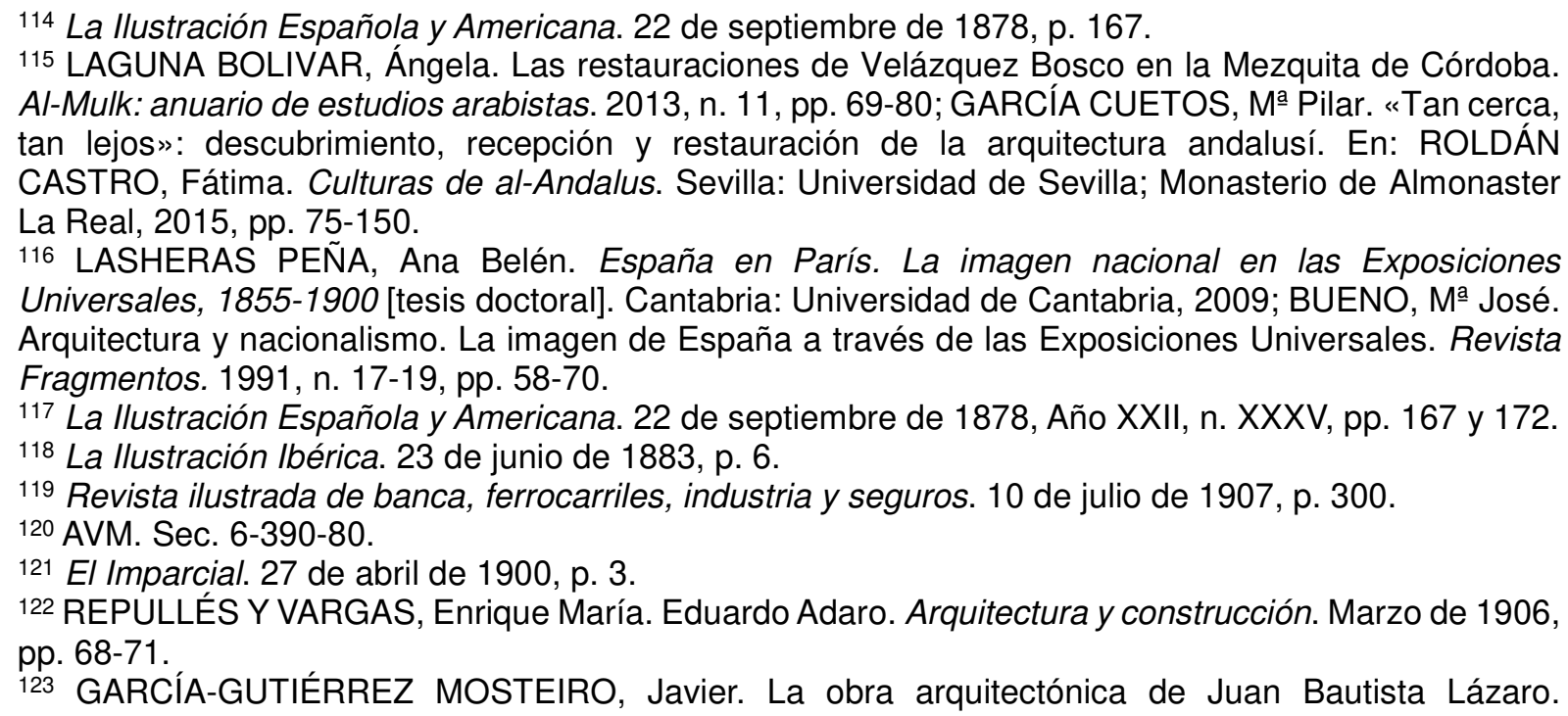
Academia. Boletín de la Real Academia de Bellas Artes de San Fernando. 1992, n. 74, pp. 445-498. 
Así lo prueba el que, en 1901, confiase a Adaro el diseño de una residencia palaciega en la calle Alfonso XII, una de las obras más valoradas de su tiempo ${ }^{124}$, donde Zaldo residió a partir de entonces, junto con sus hijas ya casadas, y estableció la sede de sus actividades empresariales, aunando, así, imagen personal y pública en un único inmueble que asume la condición de referente de identidad. Con cuatro alturas, tras el Casón del Buen Retiro, ocupa toda la manzana, ordenándose mediante un amplio patio central. Al interior no le faltó ninguna comodidad, como la instalación de diez "cuartos de baño lujosísimos", de la acreditada firma de José González de la Hoz, muy comentada por la prensa ${ }^{125}$.

A Adaro también le encargó, en 1902, la sede del Banco Hispano-Americano. A la confianza personal que en él había depositado, se unió el hecho de ser un reputado especialista en esta tipología, como arquitecto de las sedes central y provinciales del Banco de España ${ }^{126}$. Para este proyecto, dispuso de una amplia manzana de notable vocación urbanística, al erigirse en la Plaza Canalejas, con la fachada principal ligeramente achaflanada en forma cóncava con el fin de adaptarse al nuevo espacio urbano que estaba gestándose $\mathrm{e}^{127}$. En este monumental lienzo, articulado mediante el orden gigante, demuestra su dominio del lenguaje ecléctico que seguía triunfando para las empresas de mayor dimensión representativa ${ }^{128}$. Por su parte, a Juan Bautista Lázaro le encomendó varias obras, algunas muy personales. En 1889 lleva a cabo el citado inmueble de Juan de Mena en el que vivió más de una década, y en el que destaca su cuidado tratamiento de esquina achaflanada, la cual, sin embargo, no llega a adquirir presencia urbanística. Su trabajo debió resultar satisfactorio para Zaldo pues, un año después, le encargaba la construcción de un panteón en la Sacramental de San Isidro, reducido a las tumbas y el protagonismo de la cruz ${ }^{129}$, alejado de las tipologías más ostentosas que estaban poniéndose de moda ${ }^{130}$.

Aunque estas empresas las llevó a cabo en Madrid, tampoco descuidó su localidad natal, según una práctica habitual entre quienes se enriquecían en América y, al regresar, materializaban la huella de su fortuna en las poblaciones que los habían visto nacer. Así, ya en 1882, los Zaldo construyeron una notable vivienda en la plaza mayor de Pradoluengo, cuyo sencillo pero cuidado frente destacaba por su acusada verticalidad que le permitía convertirse en uno de los inmuebles de referencia de este espacio, dominado por el templo parroquial y la casa consistorial ${ }^{131}$. Once años después, Bruno culminaba otra amplia residencia en una apetecible manzana del estrecho urbanismo local que, por mímesis de la coetánea burguesía local, multiplicó sus edificaciones, transformándose en una avenida destacable dentro de las limitaciones del tradicional urbanismo rural burgalés. La retranca popular la denominó

\footnotetext{
124 NAVASCUES PALACIO, Pedro. Arquitectura y arquitectos... Op. cit., p. 277.

125 La Época. 15 de febrero de 1905, p. 2.

126 IGLESIAS ROUCO, Lena Saladina. Burgos en el siglo XIX. Arquitectura y urbanismo (1813-1900). Valladolid: Secretariado de Publicaciones de la Universidad de Valladolid, 1979, pp. 233 y 234.

127 GIMÉNEZ SERRANO, Carmen. Algunos datos sobre la reforma urbana de la Plaza de Canalejas de Madrid en el siglo XIX. Ciudad y Territorio: Revista de ciencia urbana. 1987, n. 71, pp. 55-64.

128 REPULLÉS Y VARGAS, Enrique María. Eduardo Adaro... Op. cit., pp. 68-71.

129 GARCÍA-GUTIÉRREZ MOSTEIRO, Javier. La obra arquitectónica... Op. cit., pp. 445-498.

130 SAGUAR QUER, Carlos. El cementerio de la Sacramental de San Isidro. Un Eliseo romántico en Madrid. Goya. Revista de arte. 1988, n. 202, pp. 223-231.

131 AMP. Sign. 172, 8 de abril de 1882.
} 
como "Acera de los Ricos"132. En el archivo municipal no ha quedado constancia del proyecto, pero, por sus elegantes características, se encargaría a uno de los arquitectos con los que trabajó en Madrid.

Sí sabemos que Lázaro fue el arquitecto escogido, en 1899, para llevar a cabo el proyecto del Hospital Asilo de San Dionisio ${ }^{133}$. Se planteó como un amplio núcleo horizontal en cuyo centro quedaban dispuestas las secciones comunes, permitiendo la habitual separación por sexos de los acogidos, mientras el eje central se prolongaba perpendicularmente para albergar la capilla. Aunque domina un lenguaje sencillo, pero medido, donde el único elemento de interés plástico es la utilización selectiva de los materiales, en la capilla se hace un pequeño guiño a las evocaciones neomedievalistas tan bien dominadas por Lázaro ${ }^{134}$. El interior, con bóvedas de crucería, se completó con un interesante amueblamiento, destacando las vidrieras encargadas a Guillermo Alonso Bolinaga, responsable del taller de la Catedral de León ${ }^{135}$, y un lienzo dedicado al santo protector de la institución, realizado por el pintor burgalés Marceliano Santa María, a quien Zaldo conocía ${ }^{136}$.

La firma de Santa María puede leerse en el retrato de carácter oficial de Bruno del que tenemos noticias a través de testimonios fotográficos ${ }^{137}$, realizado tras la concesión de la Gran Cruz de Isabel la Católica, posiblemente como prueba del legítimo orgullo que la distinción le produjo. Esta obra guarda estrechas relaciones con una instantánea del fotógrafo favorito de la corte y la alta sociedad madrileña, el sueco Christian Franzen ${ }^{138}$, por lo que, posiblemente, Santa María la tendría en cuenta.

Mucho antes, Zaldo confió en la pintura para retratar a sus seres queridos, según era habitual entre los indianos ${ }^{139}$. De su hija Isaura se conserva un delicado lienzo firmado por Joaquín Sorolla en 1897, en el que la joven, elegantemente vestida en vaporosos tonos grises y con largos guantes, parece estar preparada para asistir a un evento de gala, quizá su presentación en sociedad. De exquisita factura, el pintor valenciano se recrea en las texturas de los tejidos, revelando la obra la plena integración de Bruno Zaldo en los usos y costumbres de la nobleza y la alta burguesía,

\footnotetext{
132 MARTÍN GARCÍA, Juan José. Trabajo rural-Trabajo industrial... Op. cit., p. 177.

133 GARCÍA-GUTIÉRREZ MOSTEIRO, Javier. La obra arquitectónica... Op. cit., pp. 445-498.

${ }^{134}$ DÍEZ GARCÍA-OLALLA, Jorge. Juan Bautista Lázaro y la restauración monumental: su intervención en la Catedral de León (1892-1909) [tesis doctoral]. Madrid: Escuela Técnica Superior de Arquitectura de Madrid; Universidad Politécnica de Madrid, 2015.

135 BARRIO Enrique y ZAPARAÍN YÁÑ̃EZ, Maㅡ José. La iglesia soñada. Guillermo Alonso de Bolinaga en Burgos y las vidrieras de Santa María de Aranda de Duero. Revista Biblioteca. 2007, n. 22, pp. 447466.

136 PUENTE, Joaquín de la. Marceliano Santa María. Pintor de Castilla. Burgos: Caja de Ahorros del Círculo Católico de Obreros, 1976.

${ }_{137}$ Revista llustrada de banca, ferrocarriles, industria y seguros. 25 de junio de 1910.

138 ABAD ZARDOYA, Carmen. "Los usos corrientes de la aristocracia»: Construcciones de la intimidad femenina en la fotografía de sociedad de Christian Franzen. Artigrama. 2006, n. 21, pp. 525-542.

139 SAZATORNIL RUIZ, Luis. El rostro del poder: retratos de indianos, burgueses y linajes montañeses (1844-1919). En: CABAÑAS BRAVO, Miguel; LÓPEZ-YARTO, Amelia y RINCÓN GARCÍA, Wilfredo (coords.). Arte, poder y sociedad en la España de los siglos XV a XX. Madrid: Consejo Superior de Investigaciones Científicas, 2008, pp. 601-614.
} 
capaz de relacionarse con uno de los retratistas más codiciados ${ }^{140}$. Otro reputado retratista, Maximino Peña ${ }^{141}$, pintó, entre 1905 y 1909, retratos de su hijo Vicente, su esposa y una de sus hijas. Aunque desconocemos sus características, fueron apreciados por la prensa, dado el "sorprendente" parecido con los modelos ${ }^{142}$.

Los intereses de Bruno en las Bellas Artes presentaron otras facetas, y así lo avala su participación en la organización de exposiciones, como la montada sobre Arte español e Industrias decorativas por la Colonia española en México, con el fin de conmemorar el centenario de su independencia, y que contó con un comité central en Madrid presidido por Basagoiti, del que formó parte Zaldo ${ }^{143}$.

Tan profusa actividad profesional, adobada de una intensa vida social y cultural, conjugando arte y poder, negocios y filantropía, fue remitiendo a partir de 1913. Desde entonces, Bruno comenzó a pasar en su localidad natal, no solo el veraneo, sino temporadas más largas. Desde allí, hasta la cercana Villagalijo, de donde procedían sus abuelos, paseaba habitualmente, con paradas en un poyo de grandes dimensiones que mandó colocar a medio camino y que, aún hoy, conserva sus iniciales.

Bruno Zaldo murió el 28 de agosto de 1916 en el pueblo que le había visto nacer casi ochenta años antes, recibiendo sepultura en el panteón familiar mediante funeral de primera clase, "habiendo acompañado la banda de música de esta villa a la conducción del cadáver"144. El Ayuntamiento acordaba que, "haciéndose intérprete del sentir general del vecindario", se consignase en las actas municipales, "el sentimiento profundo que le ha causado la muerte del hijo más ilustre de Pradoluengo, Don Bruno Zaldo, que tantos beneficios hizo a su pueblo natal por el grande amor que siempre le profesó, suplicando respetuosamente a la familia del difunto, tengan la amabilidad de proporcionar al Ayuntamiento un retrato del mismo para ponerle en lugar preferente en el salón de sesiones"145. Si alguna vez lo hubo, en la actualidad, tal retrato no existe.

\section{Conclusiones}

Bruno Zaldo es un magnífico representante, no solo del emigrante que, triunfando económica y socialmente, vuelve a su casa con la aureola del rico "indiano" -concepto que, por cierto, no le define íntegramente- sino de un personaje que, por su longevidad, resume en su figura el trascendental cambio operado a nivel mundial mediante el desarrollo económico contemporáneo. Como hombre de su época, no solo bailó al compás de la trepidante velocidad que imprimía la nueva partitura de la segunda revolución industrial y del imperialismo capitalista, sino que, cual virtuoso

140 MARTÍNEZ DE LA PERA CELADA, Eloy; DELGADO BELLÓN, Lorena y CARRON DE LA CARRIERE, Marie-Shopie. Sorolla y la moda. Madrid: Museo Thyssen-Bornemisza, 2018, pp. 104 y 105.

${ }^{141}$ CERRILLO RUBIO, Mำ Lourdes. Maximino Peña. Vida y obra. Soria: Ayuntamiento de Soria, 1993.

142 La Correspondencia de España. 21 de abril de 1909, p. 5.

143 La Industria Nacional. 29 de junio de 1910, pp. 90 y 91.

${ }^{144}$ APP. Libro de defunciones, 1916. Curiosamente, en su partida de defunción se afirma que murió a la edad de 81 años, pero no llegó por poco tiempo a 80.

145 AMP. Sign. 188, fol. 40. 29 de agosto de 1916. 
solista, se adelantó en el emprendimiento de novedosas actividades de rabiosa modernidad en los campos económico y social. Desde sus orígenes, como comerciante en el emporio mexicano de Veracruz, aprendió rápidamente a aplicar los esquemas de funcionamiento de aquellas empresas que bebían en precedentes interseculares -de hecho, hundían sus raíces en el Setecientos colonial-, sin acomodarse en el sistema sino dando nuevo impulso a estas estructuras mediante su implicación en negocios financieros y diversificación de inversiones, desde la industria a los servicios, pasando por las producciones agroalimentarias o los transportes. Para ello, en exitoso alambique que se retroalimentaba, destiló una red de familiares, asentada en un primer momento en la tradicional llamada al otro lado del Océano de los más directos -todos sus hermanos varones- que expandió, posteriormente, a parientes y paisanos. También se ayudó de figuras expertas que le podían reportar beneficios económicos y relaciones personales de interés, casos de apoderados como Lafuente o de personajes clave como su colega Basagoiti.

Cuando retornó a España, no volvió para vivir de las rentas, supo aprovechar las nuevas oportunidades de negocio que ofrecía la expansiva etapa de la Restauración, fundamentalmente en los sectores de la construcción y la banca, aunque sin dejar de lado ninguna otra rama de actividad que le pareciese atractiva. Por tanto, en el planteamiento, nacimiento y desarrollo de sus negocios, no solo aprovechó sus réditos económicos, sino que, de forma fundamental, lo hizo de sus relaciones sociales, rodeándose de los mejores peritos en cada una de las secciones del amplio espectro de su cartera. Su introducción en la política la podemos explicar desde este punto de vista, tanto por abrirle un mundo insospechado de nuevas oportunidades, como por consolidar lo ya conseguido. Su presencia en la vida pública tuvo facetas que evidenciaron múltiples intereses, al tiempo que contribuyeron a construir su imagen como exitoso hombre de negocios, que no fue insensible a las disfunciones sociales del sistema, siendo complicado incluir sus actuaciones en categorías excluyentes.

Tras su instalación en Madrid, y de forma progresiva, se fue haciendo un hueco en la vida social de la Corte, hasta convertirse en un personaje recurrente de la misma, sin perder nunca los resortes de relación con su referencia americana a través de asociaciones y banca. Desempeñó un interesante papel en el desarrollo urbanístico del ensanche madrileño, no puesto de manifiesto hasta este momento, y estableció una compleja y sugestiva relación con el mundo de la arquitectura, también desconocida, que revela las diferentes formas que tuvo de entenderla. Si, en un primer lugar, constituyó un negocio más dentro de su diversificada actividad económica, pronto la convirtió en una forma de promover sus industrias, descubriendo, paso a paso, su potencial como marca de identidad, tanto personal y familiar, como de hombre de negocios. Tampoco descuidó la función social que la arquitectura podía desempeñar y, en cualquier caso, parece que, por su practicidad, se identificó mejor con ella que con las restantes manifestaciones artísticas, dejando a sus descendientes la creación de una imagen de moda a través del retrato.

Su sentido práctico y su carácter humano le hizo ser receptivo ante el mundo que le rodeaba. De ahí que el espíritu filantrópico le acompañase desde la primera hora de su éxito hasta más allá de su muerte, quizá por tener asumida, de forma latente, su procedencia humilde y, por tanto, conocer las dificultades que acechaban a los 
miembros de las capas menos favorecidas de la sociedad. Un ejemplo paradigmático de esta preocupación la mostró, hasta el final, con su patria, demostrando que, en su pensamiento, nunca olvidó su origen necesitado en un pequeño rincón de la Sierra de la Demanda y las duras condiciones de vida de sus laboriosos convecinos, que habían creado una mentalidad sui géneris, por mor de unas características sociológicas particulares en el contexto castellano.

\section{Fuentes}

\section{a) Archivos}

Archivo de la Ciudad de Arganda del Rey (ACAR).

Archivo de la Villa de Madrid (AVM).

Archivo del Congreso de los Diputados.

Archivo Histórico de Protocolos de Madrid (AHPM).

Archivo Histórico Municipal de Veracruz (AHMV).

Archivo Histórico Nacional (AHN).

Archivo Histórico Provincial de Burgos (AHPB).

Archivo Municipal de Pradoluengo (AMP).

Archivo Parroquial de Pradoluengo (APP).

b) Hemeroteca

Archivo Diplomático y Consular de España (Madrid).

Arquitectura y construcción (Barcelona).

Boletín Oficial de la Provincia de Madrid (Madrid).

Diario oficial de avisos de Madrid Madrid).

El criterio médico (Madrid).

El Día (Madrid).

El Globo (México).

El Heraldo de Madrid (Madrid).

El Imparcial (Madrid).

El Liberal (Madrid).

El Motín (Madrid).

El mundo de los niños (Madrid).

La Ciudad Lineal (Madrid).

La Correspondencia de España (Madrid).

La Discusión (Madrid).

La Época (Madrid).

La Iberia (Madrid).

La Ilustración Española y Americana (Madrid).

La Ilustración Ibérica (Barcelona).

La Industria Nacional (Madrid).

La Unión (Madrid).

La Unión Católica (Madrid).

Revista católica de las cuestiones sociales (Madrid).

Revista contemporánea (Madrid).

Revista de la Sociedad Central de Arquitectos (Madrid). 
Revista de las existencias de ropa de Zaldo Hermanos y Cía (Veracruz). Revista Ilustrada de Banca, Ferrocarriles, Industria y Seguros (Madrid). Revista Minera, Metalúrgica y de Ingeniería (Madrid).

\section{Bibliografía}

ABAD ZARDOYA, Carmen. "Los usos corrientes de la aristocracia»: Construcciones de la intimidad femenina en la fotografía de sociedad de Christian Franzen. Artigrama. 2006, n. 21, pp. 525-542.

ALBERICH GONZÁLEZ, Joan. El ferrocarril de la Cerámica Madrileña. Revista de Historia Ferroviaria. 2017, n. 19, pp. 7-17.

ÁLVAREZ GILA, Óscar y AMORES CARREDANO, Juan Bosco (coords.). Del espacio cantábrico al mundo americano. Perspectivas sobre migración, etnicidad y retorno. Bilbao: Universidad del País Vasco, 2015.

ARAMBURU-ZABALA HIGUERA Miguel Ángel y SOLDEVILLA ORIA, Consuelo. Arquitectura de los indianos en Cantabria (siglos XVI-XX). El patrimonio de la emigración Trasatlántica. Santander: Ediciones Librería Estudio, 2007.

ARBELO GARCIA, Adolfo. Correspondencia canario-americana: familia y redes sociales (siglos XVIII y XIX). Madrid: Idea, 2011.

AZCONA PASTOR, José Manuel. Los fundamentos de la emigración española hacia América (siglos XVI-XXI). En: AZCONA PASTOR, José Manuel; MARTín DE LA GUARDIA, Ricardo y PÉREZ SÁNCHEZ, Guillermo A. (eds.). España en la era global (1492-1898). Madrid: Sílex Universidad, 2017, pp. 361-404.

AZCONA PASTOR, José Manuel (ed.). Identidad y estructura de la emigración vasca y navarra hacia Iberoamérica siglos (XVI-XXI). Thomson Reuters Aranzadi, 2015.

BAHAMONDE MAGRO, Ángel y TORO MÉRIDA, Julián. Burguesía, especulación y cuestión social en el Madrid del siglo XIX. Madrid: Siglo Veintiuno de España, 1978.

Banco Hispano Americano. El primer medio siglo de su historia. Madrid: Imprenta Maestre, 1951.

BARRIO Enrique y ZAPARAÍN YÁÑEZ, Ma José. La iglesia soñada. Guillermo Alonso de Bolinaga en Burgos y las vidrieras de Santa María de Aranda de Duero. Revista Biblioteca. 2007, n. 22, pp. 447-466.

BLANCO RODRíGUEZ, Juan Andrés (ed.). El asociacionismo en la emigración española a América. Zamora: Junta de Castilla y León, 2008.

BUENO, Mํㅡㄹ José. Arquitectura y nacionalismo. La imagen de España a través de las Exposiciones Universales. Revista Fragmentos. 1991, n. 17-19, pp. 58-70. 
CABALLERO BARRAL, Borja. El Madrid burgués: el ensanche Este de la capital, (1860-1931) [tesis doctoral]. Madrid: Universidad Complutense de Madrid, 2015.

CARASA SOTO, Pedro (dir.). Élites castellanas de la Restauración. Diccionario biográfico de parlamentarios castellanos y leoneses (1876-1923). Valladolid: Junta de Castilla y León, 1997.

CARBALLO, Borja; PALLOL, Rubén y VICENTE, Fernando. El Ensanche de Madrid. Historia de una capital. Madrid: Editorial Complutense, 2008.

CERRILLO RUBIO, Mํㅡㄴ Lourdes. Maximino Peña. Vida y obra. Soria: Ayuntamiento de Soria, 1993.

CERUTTI PIGNAT, Mario. Empresarios españoles y sociedad capitalista en México (1840-1920). Colombres: Archivo de Indianos, 1995.

CERUTTI PIGNAT, Mario. Españoles y empresariado en el norte de México. Los papeles del vasco José San Román. América Latina en la Historia Económica. 1998, vol. 5, n. 9, pp. 17-24.

CHAVES MARTíN, Miguel Ángel. Arquitectura y urbanismo en la ciudad de Segovia (1750-1950). Segovia: Cámara de la Propiedad Urbana de Segovia, 1998.

DÍEZ GARCÍA-OLALLA, Jorge. Juan Bautista Lázaro y la restauración monumental: su intervención en la Catedral de León (1892-1909) [tesis doctoral]. Madrid: Escuela Técnica Superior de Arquitectura de Madrid; Universidad Politécnica de Madrid, 2015.

DOMÍNGUEZ MARTÍN, Rafael y CERUTTI PIGNAT, Mario (coords.). De la colonia a la globalización: empresarios cántabros en México. Santander: Universidad de Cantabria, 2006.

DOMÍNGUEZ MARTíN, Rafael. Empresarios y hombres de negocios cántabros en México durante los siglos XIX y XX. Revista de la historia de la economía y de la empresa. 2008, n. 2, pp. 155-180.

EIRAS ROEL, Antonio (coord.). La emigración española a Ultramar, 1492-1914. Madrid: Tabapress, 1991.

GÁRATE OJANGUREN, Montserrat. Los modelos de trasvases de capitales de América a Europa e inversiones en el siglo XIX. En: BEASCOECHEA GANGOITI, José María; NOVO LÓPEZ, Pedro A. y GONZÁLEZ PORTILLA, Manuel (eds.). La ciudad contemporánea, espacio y sociedad. Bilbao: Universidad del País Vasco, 2006, pp. 737-766.

GÁRATE OJANGUREN, Montserrat. Circuitos comerciales y financieros entre México y Europa (1800-1850): la participación vasca. En: YUSTE LÓPEZ, Carmen y SOUTO MANTECÓN, Matilde (coords.). El comercio exterior de México: 1713- 
1850. México: Instituto de Investigaciones Históricas; UNAM-Universidad Veracruzana, 2000, pp. 223-259.

GARCÍA-GUTIÉRREZ MOSTEIRO, Javier. La obra arquitectónica de Juan Bautista Lázaro. Academia. Boletín de la Real Academia de Bellas Artes de San Fernando. 1992, n. 74, pp. 445-498.

GARCÍA CUETOS, Mำ Pilar. «Tan cerca, tan lejos»: descubrimiento, recepción y restauración de la arquitectura andalusí. En: ROLDÁN CASTRO, Fátima. Culturas de al-Andalus. Sevilla: Universidad de Sevilla; Monasterio de Almonaster La Real, 2015, pp. 75-150.

GIMÉNEZ SERRANO, Carmen. Algunos datos sobre la reforma urbana de la Plaza de Canalejas de Madrid en el siglo XIX. Ciudad y Territorio: Revista de ciencia urbana. 1987, n. 71, pp. 55-64.

Guía Oficial de España. Madrid: Imprenta Nacional, 1878.

GRANADOS GARCÍA, Aimer. Las juntas patrióticas de españoles en México ante el 98: patriotismo, disidencia y proselitismo político. Historia mexicana. 2000, vol. 49, n. 3, pp. 379-429.

HERNÁNDEZ GONZÁLEZ, Manuel. La emigración canaria a América a través de la historia. Cuadernos Americanos. 2008, vol. 4, n. 126, pp. 137-172.

IDOATE ANCÍN, Raquel. Emigración de la Navarra atlántica a América en el siglo XIX (1840-1874) [tesis doctoral]. Navarra: Universidad Pública de Navarra, 2020.

IGLESIAS ROUCO, Lena Saladina. Burgos en el siglo XIX. Arquitectura y urbanismo (1813-1900). Valladolid: Secretariado de Publicaciones de la Universidad de Valladolid, 1979.

KUNTZ FICKER, Sandra (coord.). Historia económica general de México. De la colonia a nuestros días. México: El Colegio de México; Secretaría de Economía, 2010.

LAGUNA BOLIVAR, Ángela. Las restauraciones de Velázquez Bosco en la Mezquita de Córdoba. Al-Mulk: anuario de estudios arabistas. 2013, n. 11, pp. 69-80.

LASHERAS PEÑA, Ana Belén. España en París. La imagen nacional en las Exposiciones Universales, 1855-1900 [tesis doctoral]. Cantabria: Universidad de Cantabria, 2009.

LIDA, Clara Eugenia. Los españoles en el México independiente: 1821-1950. Un estado de la cuestión. Historia mexicana. 2006, vol. 56, n. 2, pp. 213-260.

LIDA, Clara Eugenia (comp.). Una inmigración privilegiada. Comerciantes, empresarios y profesionales españoles en México en los siglos XIX y XX. Madrid: Alianza Editorial, 1994. 
LLADOS Y RIUS, Magín. Nueva fábrica en Madrid: la Cerámica Madrileña. Revista Minera. 1880, n. 237, pp. 217-218.

MARICHAL, Carlos. De la Banca privada a la gran banca. Antonio Basagoiti en México y España, 1880-1911. Historia mexicana. 1999, vol. 48, n. 4, pp. 767-793.

MARICHAL, Carlos. Empresarios españoles de ida y vuelta en el México porfiriano y en la España de la restauración. El caso de Antonio Basagoiti y Arteta, 1880-1910. Les Cahiers ALHIM. Amèrique Latine. Histoire \& Mémoire. 2009, n. 17, pp. 149168.

MARTÍN GARCÍA, Juan José. Trabajo rural-Trabajo industrial: Belorado y Pradoluengo (1833-1936). Burgos: Aytos. de Belorado y Pradoluengo, 2000.

MARTÍN GARCÍA, Juan José. La industria textil de Pradoluengo, 1534-2007. La pervivencia de un núcleo industrial. Valladolid: Junta de Castilla y León, 2007.

MARTÍN GARCÍA, Juan José. "Zaldo Rivera, Bruno". En: Diccionario Biográfico Español, vol. 50. Madrid: Real Academia de la Historia, 2013.

MARTÍNEZ DE LA PERA CELADA, Eloy; DELGADO BELLÓN, Lorena y CARRON DE LA CARRIERE, Marie-Shopie. Sorolla y la moda. Madrid: Museo ThyssenBornemisza, 2018.

MORALES MORENO, Humberto. Los Españoles de México: 1880-1948. Asturianos, Montañeses y Vascos en la formación de redes microsociales en la época de la emigración "en masa” y del exilio en México. Gijón: CICEE, 2010.

NAVASCUES PALACIO, Pedro. Arquitectura y arquitectos madrileños del siglo XIX. Madrid: Instituto de Estudios Madrileños, 1973.

NAVASCUÉS PALACIO, Pedro. Los autores: arquitectos, pintores y dibujantes. En: ALMAGRO GORBEA, Antonio (ed.). El legado de al-Ándalus. Las Antigüedades árabes en los dibujos de la Academia. Madrid: Real Academia de Bellas Artes San Fernando, 2015, pp. 63-79.

PALIZA MONDUATE, Mำ Teresa. El mecenazgo de los indianos en el País Vasco. Personajes, sagas y su vinculación con el arte y la filantropía (siglos XIX y XX). En: SAZATORNIL Ruiz, Luis (ed.). Arte y mecenazgo indiano: del Cantábrico al Caribe. Gijón: Ediciones Treas, 2007, pp. 435-460.

PANIAGUA MAZORRA, Ángel. Catálogo de colonias agrícolas históricas de la Comunidad de Madrid 1850-1980. Madrid: Instituto de Economía y Geografía, 2005.

PERLA, Antonio. La iniciativa industrial y artística en la porcelana y la cerámica madrileña del siglo XIX desde 1808: La Moncloa, Valdemorillo, Vallecas, los 
Zuluaga, etc. En: COLL CONESA, Jaume (coord.). Manual de cerámica medieval y moderna. Alcalá de Henares: Museo Arqueológico Regional, 2011, pp. 231-270.

PI-SUÑER LLORENS, Antonia y SÁNCHEZ ANDRÉS, Agustín. Una historia de encuentros y desencuentros: México y España en el siglo XIX. México: Secretaría de Relaciones Exteriores, 2001.

PUENTE, Joaquín de la. Marceliano Santa María. Pintor de Castilla. Burgos: Caja de Ahorros del Círculo Católico de Obreros, 1976.

REBOLLEDO KLOQUES, Octavio Bernardo. Extranjeros, nacionalismo y política migratoria en el México independiente, 1821-2000 [tesis doctoral]. Granada: Universidad de Granada, 2016.

REPULLÉS Y VARGAS, Enrique María. Eduardo Adaro. Arquitectura y construcción. Marzo de 1906, pp. 68-71.

RUEDA HERNANZ, Germán. Los españoles de allá: la emigración a América en los siglos XIX y XX. En: SAZATORNIL RUIZ, Luis (ed.). Arte y mecenazgo indiano. Del Cantábrico al Caribe. Gijón: Ed. Trea, 2007, pp. 411-434.

RUEDA HERNANZ, Germán y SOLDEVILLA ORIA, Consuelo. Españoles emigrantes en América (siglos XVI-XX). Madrid: Arco, 2000.

RUIZ DE GORDEJUELA URQUIJO, Jesús. Vivir y morir en México. Vida cotidiana en el epistolario de los españoles vasco-navarros 1750-1900. San Sebastián: Ediciones Nuevos Aires, 2011.

RUIZ DE GORDEJUELA URQUIJO, Jesús. Remesas de caudales españoles durante los primeros años del México independiente, 1821-1827. Revista complutense de Historia de América. 2016, n. 42, pp. 293-317.

RUIZ DE GORDEJUELA URQUIJO, Jesús. Retorno de los comerciantes españoles tras la independencia de México. Temas americanistas. 2016, n. 37, pp. 217-240.

RUIZ DE GORDEJUELA URQUIJO, Jesús. Emigración vasco-navarra a México a mediados del siglo XIX. De Santa Anna a Juárez, 1842-1867. Vasconia: Cuadernos de historia - geografía. 2012, n. 38, pp. 385-404.

SAGUAR QUER, Carlos. El cementerio de la Sacramental de San Isidro. Un Eliseo romántico en Madrid. Goya. Revista de arte. 1988, n. 202, pp. 223-231.

SÁNCHEZ ALBORNOZ, Nicolás (coord.). Españoles hacia América. La emigración en masa, 1880-1930. Madrid: Alianza Editorial, 1988.

SÁNCHEZ ALONSO, Blanca. The other Europeans: inmigration into Latin America and the International Labour Market (1870-1930). Revista de Historia Económica. 
Journal of Iberian and Latin American Economic History. 2007, vol. 25, n. 3, pp. 395-426.

SÁNCHEZ ALONSO, Blanca. Las causas de la emigración española, 1880-1930. Madrid: Alianza Editorial, 1995.

SÁNCHEZ ANDRÉS, Agustín y PÉREZ HERRERO, Pedro. Historia de las relaciones entre España y México, 1821-2014. Madrid: Marcial Pons, 2016.

SÁNCHEZ ANDRÉS, Agustín. La normalización de las relaciones entre España y México durante el Porfiriato (1876-1910). Historia mexicana. 1999, vol. 48, n. 4, pp. 731-766.

SAZATORNIL RUIZ, Luis. El rostro del poder: retratos de indianos, burgueses y linajes montañeses (1844-1919). En: CABAÑAS BRAVO, Miguel; LÓPEZ-YARTO, Amelia y RINCÓN GARCÍA, Wilfredo (coords.). Arte, poder y sociedad en la España de los siglos XV a XX. Madrid: Consejo Superior de Investigaciones Científicas, 2008, pp. 601-614.

SAZATORNIL RUIZ, Luis. Arte y mecenazgo indianos: del Cantábrico al Caribe. Gijón: Ed. Trea, 2007, pp. 411-434.

SAZATORNIL RUIZ, Luis. Arte y mecenazgo de los indianos montañeses: Santoña, Comillas, Valdecilla (1820-1930). En: SAZATORNIL RUIZ, Luis (ed.). Arte y mecenazgo indiano. Del Cantábrico al Caribe. Gijón: Ed. Trea, 2007, pp. 543-612.

SEPÚLVEDA MUÑOZ, Isidro. Medio siglo de asociacionismo americanista español. Espacio, Tiempo y Forma, Historia Contemporánea. 1991, n. 4, pp. 271-290.

SIERRA ÁLVAREZ, José y TUDA RODRÍGUEZ, Isabel. Las lozas de Valdemorillo: una aportación a la historia de las artes industriales madrileñas, (1845-1915). Madrid: Consejería de Educación y Cultura, 1996.

SOLÀ I PARERA, Àngels. Os americanos cataláns e o seu impacto económico en Cataluña ó longo do século XIX. Estudios migratorios. 2001, n. 11-12, pp. 141168.

SOLÀ I PARERA, Àngels. La Independencia mexicana y la salida de capitales españoles residentes en México (1810-1830). En: Industrialización $y$ nacionalismo. Actas del $1^{\circ}$ Coloquio vasco-catalán de historia. Barcelona: Universidad de Barcelona, 1985, pp. 339-354.

SOUTO MANTECÓN, Matilde. Los comerciantes españoles en Veracruz: del Imperio colonial a la República. En: LIDA, Clara Eugenia (comp.). Una inmigración privilegiada: comerciantes, empresarios y profesionales españoles en México en los siglos XIX y XX. Madrid: Alianza, 1994, pp. 52-74. 
TURISO SEBASTIÁN, Jesús. La presencia de comerciantes españoles en Veracruz: el caso de Jalapa de la Feria (siglos XVIII y XIX). En: SARMIENTO, Érica; PINHEIRO DE CARVALHO, Marieta e FLIER, Patricia (eds.) Movimientos, tránsitos \& memórias: temas e abordagens. Niterói, Río de Janeiro: Universo, 2016.

TURISO SEBASTIÁN, Jesús. Emigración, comerciantes y comercio en la región de Veracruz entre 1778-1822. Naveg@mérica, Revista electrónica editada por la Asociación Española de Americanistas [en línea]. 2019, n. 22, pp. 11-22. Disponible en <https://revistas.um.es/navegamerica/article/view/363601/258911>.

VICENTE ALBARRÁN, Fernando. Los barrios negros: el Ensanche Sur en la formación del moderno Madrid (1860-1931) [tesis doctoral]. Madrid: Universidad Complutense de Madrid, 2011.

VV.AA. La memoria de la emigración: fuentes históricas, centros y archivos para el estudio de los flujos migratorios españoles. Vigo: Grupo España Exterior, 2011.

VIVES, Pedro A.; VEGA, Pepa y OYAMBURU, Jesús (coords). Historia general de la emigración española a lberoamérica. Ministerio de Trabajo e inmigración, 1992.

ZALDO HERNÁNDEZ, Rafael. Indianos ilustres. Familia Zaldo. Burgos: Ed. del autor, 2013. 